\title{
BIAYA INTERMEDIASI KEUANGAN PERBANKAN INDONESIA: PERANAN REGULASI DAN INSTITUSI
}

\author{
(Indonesian Banking Financial Intermediation Costs: Roles of Regulation and Institution)
}

\author{
Davy Hendri \\ Fakultas Ekonomi dan Bisnis Islam IAIN Imam Bonjol Padang \\ Jl. Prof. M. Yunus No. 1 Kampus Lubuk Lintah \\ Email: davyhendri74@gmail.com \\ Naskah diterima: 06 Februari 2015 \\ Naskah direvisi: 10 Februari 2015 \\ Naskah diterbitkan: 30 Juni 2016
}

\begin{abstract}
This study discusses the determinants of net interest margin (NIM) in Indonesia using a panel dataset bank in the period from 2004-2012 which includes a sample of 42 commercial banks of all operating commercial banks. This study uses applied theory of dealership model for the analysis. This is done by incorporating several variables such as macroeconomic, institutional conditions, and regulations of banking industry. With data support that includes different type categories of banking based on the largest share ownership (State Owned Banks, foreign, and mixed bank ownership) and scope of services (foreign exchange services), fixed effect panel regression analysis is performed by comparing specific characteristics of each of the bank. The study results show that indeed the specific characteristics of bank, such as size, liquidity, and market forces, as well as the structure of the markets in which a bank operates, explain most of NIM variation. However, regulation and institutional quality do not sufficiently help explain costs variations in the financial intermediation. These findings are quite different from those of mainstream findings of banking study in developed countries. It can at least be explained by the possible level of Indonesian banking regulations that actually have reached the maximum standards and the possibility of regulatory indicators that can not be seen isolated from the structure of ownership rights and competition in banking industry that has earlier taken place. There is great potential to promote banking competition policies and strengthen institutional frameworks in order to further reduce the cost of intermediation of the banking system.

Keywords: net interest margins, market structure, macroeconomy, good governance
\end{abstract}

\begin{abstract}
Abstrak
Studi ini membahas faktor-faktor penentu margin suku bunga (NIM) di Indonesia dengan menggunakan dataset panel bank periode tahun 2004-2012 yang mencakup sampel 42 bank umum komersial dari keseluruhan bank yang beroperasi. Studi ini menggunakan pengembangan teori dealership model dalam analisis guna menentukan variabel dominan penentu NIM. Hal ini dilakukan dengan memasukkan variabel kondisi makroekonomi, kelembagaan, dan regulasi dalam dunia perbankan. Dengan data perbankan yang mencakup kategori perbankan menurut kepemilikan saham terbesar (BUMN, asing, dan campuran) dan lingkup pelayanan (devisa), analisis regresi panel fixed effect dilakukan dengan mengkomparasikan determinan karakteristik khusus (time-variant) masing-masing bank tersebut. Hasil analisis studi ini menemukan fakta bahwa memang karakteristik spesifik perbankan, seperti ukuran, likuiditas, dan kekuatan pasar, serta struktur pasar di mana bank beroperasi, menjelaskan sebagian besar variasi NIM. Namun regulasi dan kualitas institusi ternyata tidak cukup membantu menjelaskan variasi biaya intermediasi keuangan ini. Temuan ini memang berbeda jauh dengan temuan pada studi perbankan pada negara maju. Hal ini setidaknya bisa dijelaskan oleh kemungkinan level regulasi perbankan Indonesia yang justru sudah pada standar maksimum dan kemungkinan indikator regulasi tidak bisa dipandang terisolasi dari struktur hak kepemilikan dan kompetisi yang sudah terbangun dalam dunia perbankan sebelumnya. Namun secara umum, hasil analisis menunjukkan bahwa ada potensi besar kebijakan untuk mendorong persaingan perbankan dan memperkuat kerangka kerja institusional guna lebih mengurangi biaya intermediasi sistem perbankan.

Kata kunci: net interest margin, struktur pasar, makroekonomi, tata kelola yang baik
\end{abstract}

\section{PENDAHULUAN}

\section{A. Latar Belakang}

Industri perbankan di Indonesia merupakan industri yang paling menguntungkan dibandingkan industri serupa di negara-negara anggota G20 lainnya (OECD, 2015). Industri perbankan di Indonesia beberapa tahun belakangan ini menikmati laba besar bahkan keuntungan ini lebih besar 2 kali lipat dibandingkan dengan perbankan di Amerika Serikat. Rata-rata return on equity (ROE) perbankan Indonesia adalah sebesar 23 persen. Lebih besar jika dibandingkan dengan negara lain seperti Tiongkok, yang hanya memiliki nilai return sebesar 21 persen, Kanada sebesar 20 persen, atau lebih besar dua kali dari Amerika Serikat yang hanya memiliki return sebesar 9 persen.

Keuntungan ini didorong oleh besarnya $\mathrm{Net}$ Interest Margin (selanjutnya dibaca NIM). Rata-rata marjin bank-bank besar adalah sebesar 7 persen, di mana rata-rata suku bunga pinjaman adalah 12 persen dan rata-rata suku bunga dana pihak ketiga adalah 5 persen. Nilai ini adalah yang tertinggi di antara negara-negara anggota G20. Tidak hanya level global, bahkan pada level regional posisi NIM industri 


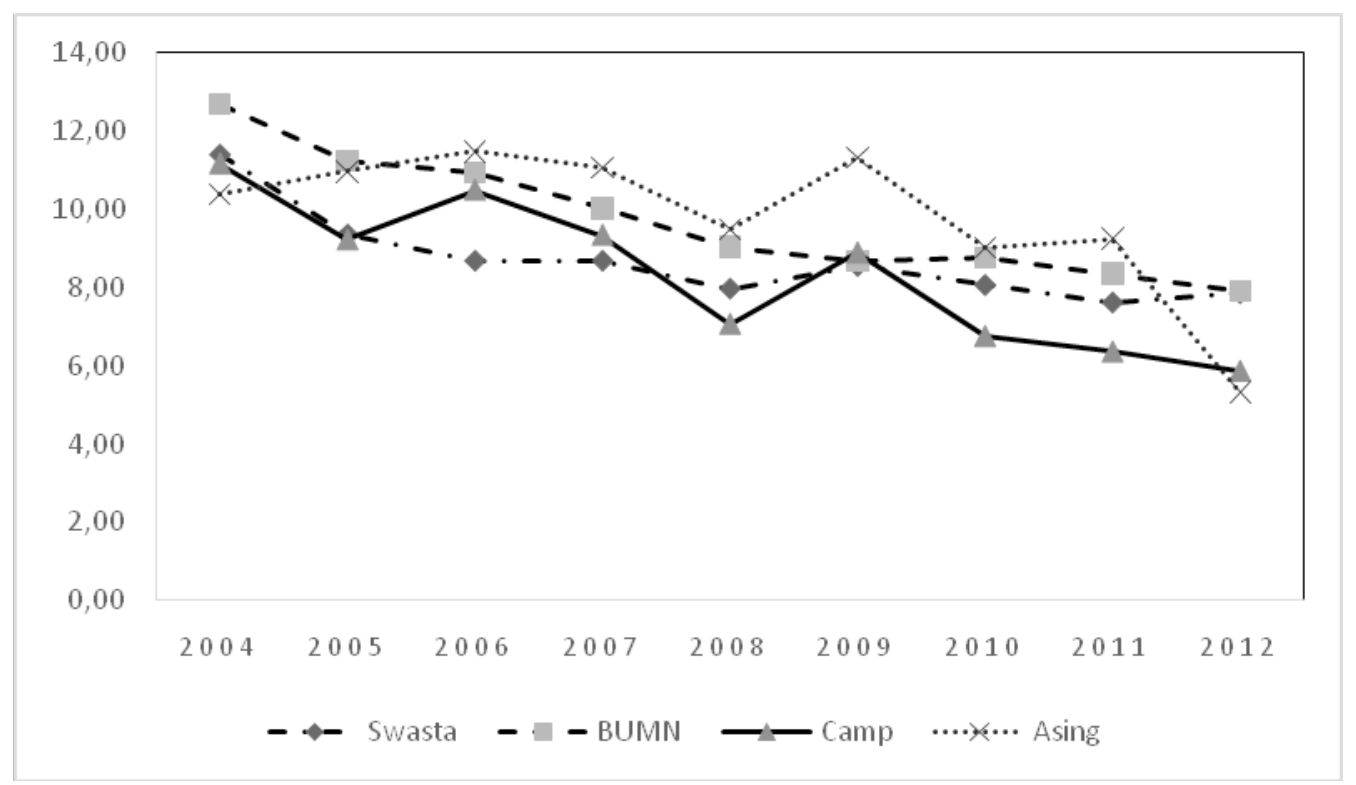

Sumber: Bank Indonesia dari berbagai tahun (diolah).

Gambar 1. Rerata NIM Perbankan di Indonesia berdasarkan Kelompok Bank

perbankan nasional tersebut masih jauh lebih tinggi bila dibandingkan dengan negara lain sesama kelompok negara berpendapatan menengah, seperti Filipina dan Thailand, dengan NIM berturut-turut hanya 3,3 persen dan 2,6 persen (ADB, 2015).

Sementara itu pada level nasional, kelompok perbankan dengan NIM tertinggi didominasi oleh perbankan besar, terutama dari perbankan pelat merah (BUMN). Gambar 1 memperlihatkan bahwa sampai akhir tahun 2012, NIM perbankan pelat merah ini merupakan yang tertinggi dibandingkan dengan NIM kelompok perbankan lainnya. Walaupun mengalami trend penurunan pasca krisis global tahun 2008, namun level NIM bank dalam kelompok BUMN dan swasta besar masih jauh lebih tinggi, pada kisaran 7-8 persen, dibandingkan dengan pesaingnya dari kelompok perbankan asing dan campuran yang cuma pada kisaran 4-6 persen.

Menurut kerangka teoritis dealership model yang diperkenalkan oleh $\mathrm{Ho}$ and Saunders (1981), dan dikembangkan oleh Allen (1988), Angbazo (1997), dan Maudos and Fernandez de Guevara (2004), bank berfungsi sebagai dealer yang menghindari risiko di pasar deposito dan pinjaman, menanggung risiko refinancing karena kemungkinan ketidaksesuaian antara deposito dengan permintaan kredit. Oleh karenanya, semakin besar ekspektasi risiko yang akan ditanggung oleh perbankan dalam fungsi intermediasinya, akan semakin besar level NIM yang ditetapkan.

Dampak bagi sektor riil seperti korporasi adalah tingginya biaya utang jika mengandalkan sumber pendanaan dari perbankan nasional (dalam negeri). Dalam konteks demand-supply, jika korporasi tidak memiliki alternatif opsi sumber pendanaan yang lebih murah dari luar negeri, tingginya NIM perbankan nasional akan membebani operasional korporasi. Namun dengan telah terintegrasinya sektor keuangan secara global, tingginya "harga" utang yang dipatok oleh perbankan sebagai supplier dalam negeri, akan menggerakkan "switching" demand ke supplier luar negeri. Konsekuensinya, kebutuhan dana besar akan membuat korporasi mencari pembiayaan ke luar negeri, dimana "harga" utang lebih rendah dan kemampuan dalam memberikan pembiayaan berskala besar.

Dalam konteks kekinian, perbankan luar negeri bahkan bisa hadir leluasa di Indonesia. Pertumbuhan aset dan pendanaan yang masif dari bank yang terkategori Multi National Corporation (MNC) ini dalam waktu singkat sejak kehadirannya di Indonesia, di satu sisi memperkuat fakta betapa menggiurkannya potensi keuntungan dari sektor perbankan di Indonesia. Di sisi lain, memberikan harapan terjadinya proses pembelajaran dunia perbankan nasional dalam hal efektivitas dan efisiensi kinerja yang dimiliki perbankan negara lain. Sebagai wujud efisiensi, diharapkan hal ini akan berujung kepada semakin menurunnya NIM perbankan nasional.

Hal ini sejalan dengan kritikan faktual atas kerangka teoritis dealership model. Model ini tidak memperhitungkan perbedaan dalam kondisi ekonomi makro, kelembagaan, dan lingkungan regulasi di negara mana bank itu beroperasi. Oleh karena itu, dalam berbagai penelitian lintas negara mengenai determinan NIM, biasanya selalu menambahkan motivasi teoritis determinan NIM dengan variabel karakteristik tertentu-milik negara yang bersangkutan (lihat Brock and Rojas-Suarez, 
2000; Claessens, Demirguc-Kunt and Huizinga, $H$, 2001; dan Demirguc-Kunt, Laeven, and Levine, 2004).

Namun di sisi lain, di balik pilihan opsi kebijakan apapun, selalu ada risiko yang harus ditanggung (no free lunch). Kehadiran perbankan MNC, khususnya dengan layanan produk dan jasa pinjaman dalam bentuk mata uang asing terutama US Dollar, akan meningkatkan currency exposure. Trend penguatan US Dollar, kelambatan ekonomi nasional membuat korporasi dalam negeri yang beroperasi dan mendapatkan keuntungan dalam rupiah, akan kesulitan mengembalikan pinjaman berdenominasi US Dollar. Selain berujung kepada ekonomi biaya tinggi (high cost economy), di sisi lain, biaya intermediasi keuangan yang tinggi merupakan hambatan penting bagi financial deepening ${ }^{1}$ di dalam negeri terutama pada negara yang terkategori Low Income Countries (LICS).

\section{B. Permasalahan}

Beragam penelitian menunjukkan bahwa biaya intermediasi keuangan memiliki dampak penting bagi kinerja ekonomi (Jayaratne and Strahan, 1996; Rajan and Zingales, 1998; Beck, Demirguc-Kunt and Levine, 2000). Indikator NIM sebagai ukuran biaya intermediasi keuangan, berperan penting khususnya bagi negara-negara LICs. Pada negara dalam kategori ini, saat industri keuangan lain belum berkembang maka perekonomian sangat tergantung pada perbankan sebagai sumber pendanaan yang utama.

Beberapa penelitian mengungkapkan bahwa rigid-nya NIM yang tinggi merupakan gejala dari sejumlah masalah sistemik. Menariknya, pada sisi mikro, beberapa teori memberikan prediksi bertentangan tentang hubungan antara peraturan, konsentrasi, lembaga, dan efisiensi perbankan. Banyak dari perbedaan ini muncul karena perbedaan tentang penyebab konsentrasi perbankan. Salah satu pandangan umum menyatakan bahwa hambatan regulasi untuk berkompetisi dan kekuatan monopoli telah menciptakan suatu lingkungan di mana beberapa bank yang kuat akan menghalangi persaingan dengan implikasi merugikan efisiensi. Dari perspektif ini, konsentrasi yang tinggi merupakan sinyal dari tidak kompetitif dan tidak efisiennya

Konsep financial deepening ditunjukkan oleh beberapa indikator, salah satunya rasio kredit domestik terhadap PDB (domestic credit as a percentage of GDP). Di mana pada tahun 2013 untuk Indonesia rasionya masih di bawah 40 persen, dibandingkan dengan Singapura yang telah mencapai sekitar 130 persen dan Malaysia sekitar 125 persen (Economic and Financial Indicators, ADB). Pada rentang krisis ekonomi tahun 1997-2012, rasio kredit domestik untuk sektor swasta (domestic credit to private sector) turun dari 61 persen menjadi 35 persen (OECD Economic Survey 2015, OECD). pasar. Sebagai alternatif, "efficient-structure" theory berpendapat bahwa bank yang lebih efisien akan mempunyai pangsa pasar yang lebih besar (Demsetz, 1973 dan Peltzman, 1977).

Dari perspektif ini, justru lingkungan yang kompetitif dapat menghasilkan sistem perbankan yang terkonsentrasi dan efisien. Pada sisi makro, konsentrasi dan regulasi perbankan, merefleksikan karakteristik institusional yang lebih luas daripada sekedar menjadi determinan dari efisiensi sektor perbankan. Lingkungan kelembagaan yang tidak kondusif dan adanya berbagai kendala regulasi juga turut mendistorsi aktivitas pasar keuangan. Beberapa studi bahkan memperlihatkan bahwa deregulasi industri perbankan terkadang dapat memiliki efek yang tidak diinginkan dan mendestabilisasi sistem keuangan, menimbukan ketidakstabilan ekonomi makro, dan dalam beberapa kasus, memperlambat pertumbuhan ekonomi (Moyo, et al., 2014).

Kondisi lingkungan yang berbeda akan memberikan hasil yang berbeda terhadap level efisiensi perbankan yang tercermin pada indikator NIM. Dalam konteks ini, kondisi lingkungan struktur pasar, regulasi, dan institusi yang melingkupi perbankan di negara maju sudah pasti berbeda dengan di negara berkembang. Oleh sebab itu, hal ini akan memberikan efek berbeda pula (no one size fit for all) terhadap indikator NIM. Pada konteks Indonesia, timbul pertanyaan menarik untuk dijawab, yaitu mengapa dalam rejim regulasi perbankan yang relatif liberal, NIM perbankan Indonesia masih tetap tinggi dan rigid?. Ataukah memang karakteristik masing-masing perbankan sama sekali menegasikan dampak peran regulasi dan institusi terhadap variasi NIM?. Lebih jauh, apakah memang tidak ada resep efisiensi yang generik bagi sektor perbankan di Indonesia?.

\section{Tujuan}

Tujuan utama dari penelitian ini adalah untuk menguji pengaruh konsentrasi pasar, peraturan perbankan, pengembangan kelembagaan, dan lingkungan ekonomi makro pada NIM industri perbankan di Indonesia, sekaligus mengontrol faktor bank yang spesifik. Penelitian ini merujuk kepada studi yang dilakukan oleh Demirguc-Kunt, Laeven, dan Levine, (2004) dengan menggunakan variabel yang sama, namun dengan cakupan data lintas negara. Studi tersebut memiliki keunggulan karena bisa mengobservasi perbedaan karakteristik regulasi dan institusi antarnegara.

Lebih lanjut kelemahan penelitian dalam konteks satu negara diatasi dengan menggunakan data yang mencakup bank dengan kepemilikan (saham terbesar) yang bervariasi. Dalam hal ini, komparasi 


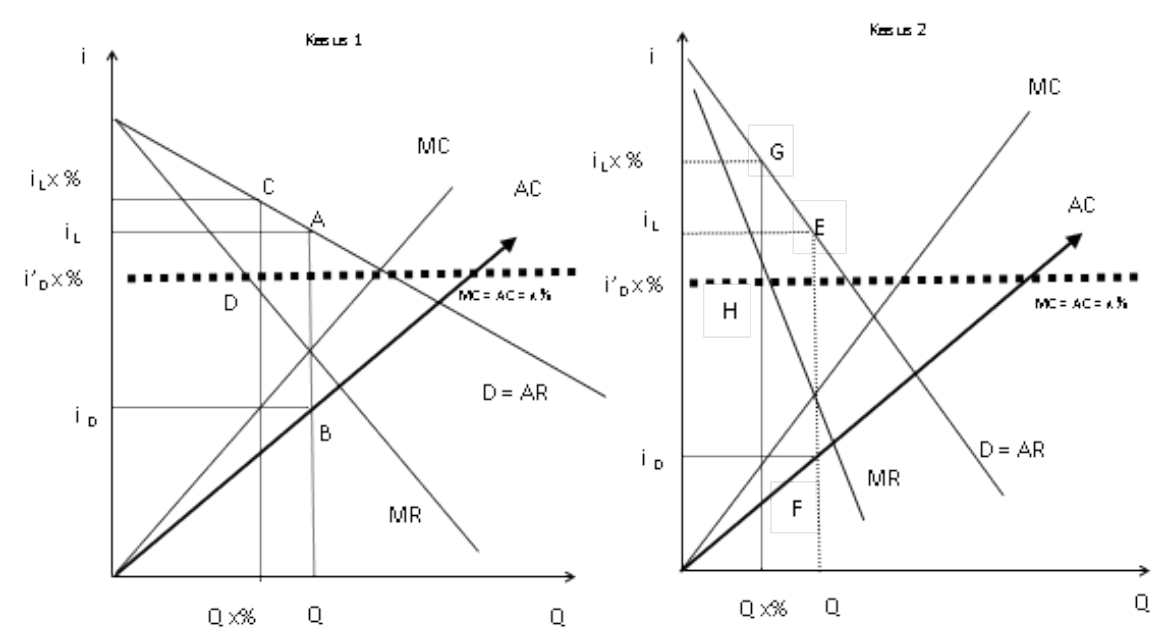

Sumber: Randall (1998).

Gambar 2. Variasi Perubahan NIM Menurut Variasi Elastisitas Permintaan

pada dua kutub ekstrim kepemilikan bank, antara asing (bank asing) dan pemerintah (bank BUMN) diasumsikan akan memberi dampak kepada perilaku mereka sebagai efek dari proses internalisasi regulasi dari negara asalnya. Dalam hal ini, penelitian ini menggunakan dua indikator subjektif sebagai proksi internalisasi yang mewarnai perilaku bank, yaitu preferensi risiko dan risiko kredit. Kedua indikator ini akan menentukan respon perbankan terhadap dinamika pasar di manapun mereka beroperasi.

\section{KERANGKA TEORI}

\section{A. Biaya Intermediasi Perbankan-Struktur Pasar} dan Regulasi (Intervensi)

Dalam konteks penetapan harga (pricing) suatu produk oleh perusahaan, struktur pasar produk tadi akan memengaruhi profit (revenue-cost) perusahaan. Kebijakan intervensi pemerintah, baik tidak langsung maupun langsung ${ }^{2}$, dalam struktur pasar yang berbeda akan disikapi berbeda pula oleh perusahaan. Lebih jauh, bahkan dalam satu model pasar, seperti pasar yang cenderung monopoli (oligopoli dan monopoli), perbedaan perilaku perusahaan bisa terjadi. Semakin besar derajat monopoli suatu perusahaan, semakin besar juga peluang mereka menjadi price leader (setter).

Selain itu, struktur pendapatan (revenue) dan biaya (cost) dari masing-masing perusahaan juga amat menentukan. Dalam struktur pasar apapun, semua perusahaan mempunyai peluang untuk tutup beroperasi dan memutuskan untuk keluar dari pasar. Hal ini akan terjadi jika harga produk yang mereka jual, ternyata lebih rendah dari total biaya rataratanya, average (total) cost $(\mathrm{P}<\mathrm{AC})$. Ketika biaya

\footnotetext{
Intervensi langsung pemerintah di antaranya berupa kebijakan himbauan moral, insentif, dan sejenisnya. Sementara itu intervensi langsung bisa berupa kebijakan ceiling price dan floor price.
}

tadi didekomposisi menjadi biaya tetap (fixed cost selanjutnya disebut FC) dan biaya variabel (variable cost, selanjutnya disebut VC) maka untuk tetap bisa beroperasi dalam jangka pendek, minimal perusahaan harus bisa menutupi biaya variabel ratarata, average variable cost (AVC).

Dalam konteks studi ini, jika intervensi tadi berbentuk kebijakan dari regulator (dalam hal ini BI), secara langsung maupun tidak langsung, akan berdampak beragam terhadap suku bunga pinjaman, suku bunga deposito. Pada gilirannya hal ini akan berdampak pula pada NIM. Sebagai konsekuensinya, perbankan juga akan berperilaku beragam,sesuai penguasaan mereka atas pasar (Petersen and Rajan, 1995), struktur pendapatan, dan biaya. Sebagai contoh, Randall (1998), menjelaskan bahwa dengan struktur biaya tertentu, kebijakan minimum suku bunga deposit (floor price) akan berdampak ambigu (bisa efektif maupun tidak). Variasi perubahan NIM, yaitu selisih suku bunga kredit dengan suku bunga deposito ( $\mathrm{i}_{\mathrm{L}}$ $\left.i_{D}\right)$, perbankan akan sangat beragam. Hal ini sangat bergantung kepada elastisitas permintaan (kurva AR).

Dalam Gambar 2 kasus 1 (diasumsikan struktur biaya adalah given) semakin landai (elastis) demand for credit yang diwakili oleh kurva Average Revenue perbankan maka kebijakan regulator tadi akan direspon perbankan dengan menaikkan suku bunga pinjaman sedikit di atas keadaan awal. Hal ini tampak dari pergerakan dari titik A ke C. Sehingga NIM yang semula ditunjukkan oleh $A B\left(i_{L}-i_{D}\right)$ akan menjadi $C D$ $\left(i_{L} x \%-i_{D} x \%\right)$. Sebaliknya dalam kasus 2, jika kurva AR perbankan semakin tidak elastis (diasumsikan struktur biaya adalah given), kebijakan yang sama akan berujung memang akan berujung kepada penurunan NIM. Pada konteks ini, penurunan yang terjadi relatif jauh lebih sedikit dibandingkan dengan kasus 1. Terlihat bahwa NIM yang semula ditunjukkan oleh $E F\left(i_{L}-i_{D}\right)$ akan menjadi $G H\left(i_{L} x \%-i_{D} x \%\right)$. 
Sementara itu, jika intervensi pemerintah dalam bentuk regulasi berujung kepada ceiling price akan direspon berbeda pula oleh perbankan. Perbankan justru merespon dengan menurunkan suku bunga pinjaman. Dengan kata lain, kebijakan ini pada dasarnya juga akan memperkecil NIM perbankan. Namun harga kredit ini relatif lebih murah dibandingkan dengan kedua kasus sebelumnya. Hal ini akan memicu pertumbuhan (ekspansi) demand for credit dan semakin memperdalam financial deepening ${ }^{3}$. Berbicara lebih jauh, jika asumsi struktur biaya direlaksasi, dengan kata lain biaya perusahaan juga bergerak dinamis (tidak konstan atau given), maka kondisi keseimbangan (equilibrium) di pasar juga menjadi lebih rumit (Neumark and Sharpe, 1992). Dalam hal ini, kondisi keseimbangan akan terjadi seiring interaksi antara elastis kedua komponen, yaitu demand for (revenue) dan supply of (cost) kredit.

Di sisi lain, dampak sebuah regulasi terhadap ekspansi (kontraksi) kredit juga berbeda. Dalam kasus 1 dan kasus 2, dari gambar bisa terlihat bahwa walaupun kenaikan suku bunga kredit adalah relatif sama ( $\left.i_{\llcorner} \times \%\right)$, namun dengan elastisitas permintaan (kurva AR) yang bervariasi, penurunan NIM juga bervariasi. Pada gilirannya, hal ini akan menyebabkan kontraksi kredit ( $Q-Q \times \%)$ juga akan bervariasi. Dalam kasus 1, penurunan NIM yang lebih kecil menyebabkan kontraksi kredit yang lebih besar dibandingkan dengan kasus 2 .

\section{B. Net Interest Margin}

NIM yang diukur sebagai perbedaan antara suku bunga kredit dan deposito, adalah ukuran yang diterima secara umum tentang seberapa mahal layanan intermediasi perbankan terhadap masyarakat. NIM didekomposisi berdasarkan metodologi yang diusulkan oleh Randall (1998). Laporan laba rugi bank mendefinisikan laba (P) sebagai pendapatan bunga (II), ditambah dengan pendapatan nonbunga (NII), dikurangi beban bunga (IP), dikurangi biaya operasional (OC), dan dikurangi penyediaan penghapusan kredit (Prov).

$$
\mathrm{P}=\mathrm{II}+\mathrm{NII}-\mathrm{IP}-\mathrm{OC}-\text { Prov }
$$

Setelah menata ulang identitas (persamaan 1) ini, NIM dapat dinyatakan sebagai:

$$
\mathrm{II}-\mathrm{IP}=\mathrm{OC}+\text { Prov }+\mathrm{P}-\mathrm{NII}
$$

Kemudian melalui rekayasa matematis membagi persamaan (2) dengan kewajiban berbunga (interest bearing liabilities) (D), akan menghasilkan

Untuk lebih mendalam, dapat dilihat pada Randall. (1998). Interest rate spreads in the Eastern Caribbean. IMF Working Paper, 98/59, Washington: International Monetary Fund.

$$
\frac{I I}{D}-\frac{I P}{D}=\frac{O C}{D}+\frac{P r o v}{D}+\frac{P}{D}-\frac{N I I}{D}
$$

Selanjutnya dengan memasukkan identitas aset menghasilkan bunga (average interest bearing assets) (L/L) ke dalam II/D pada persamaan (3) sebelah kiri dan identitas total aset (A/A) ke dalam P/D pada persamaan (3) sebelah kanan dan dengan sedikit melakukan rekayasa matematis maka akan diperoleh persamaan berikut:

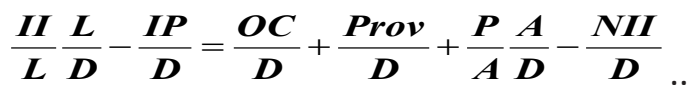

Diasumsikan bahwa karena kebijakan giro wajib mimimum di mana $L=(1-\rho) D$, maka bank hanya bisa menginvestasikan fraksi dari kewajiban berbunga (deposit) mereka menjadi aset (loan) yang menghasilkan bunga. Pada akhirnya NIM didefenisikan sebagai perbedaan antara suku bunga kredit implisit (II/L) dan suku bunga dana/deposit implisit (IP/D), yang dapat ditulis sebagai:

$$
\begin{aligned}
i_{L}-i_{D}=\rho * i_{L}+\frac{O C}{D}+\frac{P r o v}{D}+ \\
\operatorname{ROA}^{*} \frac{A}{D}-\frac{N I I}{D}+\varepsilon
\end{aligned}
$$

Persamaan (5) ini mendekomposisikan margin ke dalam komponen biaya dan keuntungan sebagai berikut:

Biaya GWM: $\rho * i$ yang tinggi membebankan biaya tambahan pada bank, karena mereka harus membayar suku bunga pasar untuk deposan tetapi harus memegang sebagian kecil dari deposito tersebut di bank sentral tanpa imbal jasa (cadangan dana pada BI namun tidak memperoleh return bunga). Bank biasanya lebih suka untuk membebankan biaya tambahan ini kepada pelanggan mereka dengan pelebaran margin.

Biaya operasional: OC/D. Variabel ini mengukur dampak efisiensi perbankan pada margin. Bank yang lebih efisien mampu mempertahankan biaya operasional yang relatif lebih rendah dibandingkan bank lain yang kurang efisien. Di sisi lain, bank itu dapat beroperasi pada margin yang lebih rendah dan mampu menghasilkan tingkat profitabilitas yang sama dengan bank lain yang kurang efisien.

Biaya penyisihan kerugian pinjaman: Prov/D. Variabel ini merupakan proksi dari dampak risiko kredit pada margin. Bank dengan portofolio pinjaman berisiko akan mentransfer sejumlah dana yang lebih besar untuk mempertahankan cadangan penyisihan kerugian kredit yang memadai. Hal ini tentu saja tidak akan menghasilkan pendapatan apapun (idle money) bagi bank dan pada gilirannya justru akan membebani margin. 
Profitabilitas: ROA*A/D. Faktor ini mendefinisikan seberapa besar margin bank yang harus ditetapkan pihak bank untuk menutupi semua biayanya sehingga bank bisa mempertahankan tingkat profitabilitas yang memadai. Dalam industri perbankan yang tidak kompetitif, bank memiliki kekuatan untuk menetapkan besaran profit yang melebihi tingkat normal dengan pelebaran margin.

Pendapatan non-bunga: NII/D (dengan tanda negatif). Bank yang mendapatkan dana dari kegiatan perbankan non-tradisional (seperti, kegiatan berbasis biaya, lisensi, asuransi, dan lain-lain) dapat mempertahankan tingkat profitabilitas yang memadai sementara mereka dapat beroperasi pada margin yang lebih rendah.

\section{METODOLOGI}

Analisis empiris dilakukan dengan menggunakan kerangka teoritis dealership model yang diperkenalkan oleh Ho and Saunders (1981), dan dikembangkan Allen (1988), Angbazo (1997), dan Maudos and Fernandez de Guevara (2004). Asumsi utama model ini adalah bank berfungsi sebagai dealer yang menghindari risiko di pasar deposito dan pinjaman, menanggung risiko refinancing karena kemungkinan ketidaksesuaian antara deposito dengan permintaan kredit.

\section{A. Spesifikasi Empiris}

Model yang digunakan di sini merupakan model ekstensifikasi dan adaptasi dari dealership model dengan menambahkan variabel tertentu terkait karakteristik perbankan dan negara tempat beroperasinya. Untuk itu, proses ekstensifikasi akan dilakukan dengan memasukkan variabel regulasi, institusi dan makroekonomi negara yang bersangkutan. Sementara itu, proses adaptasi akan dilakukan dengan merubah unit analisis dari negara menjadi unit analisis perbankan merujuk kepada perbedaan status kepemilikan saham terbesar dari perbankan, BUMN, swasta, campuran, dan asing.

Kedua proses ini dijelaskan dengan mengambil bentuk spesifikasi persamaan sebagai berikut;

$$
\begin{aligned}
\text { Margi } n_{i t}= & \alpha_{i}+\sum_{n}^{N} \beta_{n} B_{n i t-1}+\sum_{m=1}^{M} \gamma_{m} M_{m i t}+ \\
& \sum_{k=1}^{K} \lambda_{k} I_{k i t}+\sum_{l=1}^{L} \eta_{l} R_{l i t}+\varepsilon_{i t}
\end{aligned}
$$

Di mana $i$ dan $t$ secara berturut-turut mewakili bank menurut status kepemilikan dan waktu masing-masing, Margin adalah NIM, $B$ adalah vektor karakteristik bank berdasarkan status kepemilikan tersebut, sementara $M, I$, dan $R$ adalah vektor ekonomi makro, kelembagaan, dan regulasi.
Sesuai dengan tujuan penelitian ini untuk melihat dampak dari karakteristik masing-masing perbankan, maka selain karakteristik yang observable seperti kepemilikan saham mayoritas, ukuran, efisiensi, dan lain-lain, maka efek unobservable dari karakteristik heterogenitas individual bank juga perlu dimasukkan ke dalam model. Hal ini akan ditangkap oleh efek tetap intercept $\alpha_{i}^{4}$. Oleh karenanya, untuk menjawab pertanyaan studi ini, strategi estimasi akan menggunakan regresi panel data model fixed effect (FE). Semua variabel penjelas bank tertentu diambil dengan rasio untuk mereduksi potensi simultanitas.

\section{B. Variabel dan Data}

Penelitian ini akan menggunakan data karakteristik perbankan yang berasal dari statistik perbankan publikasi Bank Indonesia. Data karakteristik perbankan mencakup data given (sudah jadi) maupun data yang harus diolah sendiri untuk tujuan penelitian ini. Data ini mencakup variabel dependent, yaitu selisih antara pendapatan implisit bank dari operasional berbasis bunga dan biaya implisit yang dikeluarkan untuk menarik dana pada akun deposit (NIM).

\section{Determinan Karakteristik Perbankan}

Sejumlah variabel independent bank tertentu digunakan dalam literatur. Konsentrasi pasar ditangkap oleh indeks Herfindahl, diukur sebagai jumlah dari kuadrat pangsa pasar perbankan sesuai status kepemilikan. Total aktiva digunakan sebagai ukuran aktivitas perbankan. Sementara itu, biaya operasi diukur sebagai rasio biaya operasional terhadap total aset. Risk aversion diproksikan oleh rasio ekuitas terhadap total aset. Bank dengan rasio risk aversion yang lebih tinggi menyiratkan keengganan menanggung risiko yang lebih tinggi. Hubungan antara variabel ini dengan NIM adalah ambigu.

Risiko kredit diukur dengan rasio provisi kerugian pinjaman terhadap pinjaman bersih. Semakin besar risiko kredit terkait dengan intermediasi keuangan, semakin besar margin yang dibutuhkan oleh bank untuk berpartisipasi dalam proyek. Sementara itu, Size Ops dinyatakan dalam logaritma total aset.

\footnotetext{
Sesuai dengan tujuan penelitian, maka data akan dianalisis dengan menggunakan model regresi panel data Fixed Effect (FE). Uji Hausman pada Lampiran 2 menunjukkan bahwa untuk mengestimasi dampak karakteristik perbankan pada 2 kelompok perbankan, yaitu BUMN dan campuran, terhadap NIM-nya masing-masing, model Random Effect (RE) lebih baik dalam menjelaskannya. Namun, jika dominan model yang digunakan ternyata relatif lebih cocok dengan menggunakan model FE, maka tidaklah tepat mengkomparasikan hasil estimasi dengan model yang berbeda, beberapa menggunakan RE sementara lainnya menggunakan FE.
} 


\section{Determinan Makroekonomi (M)}

Kegiatan ekonomi diukur dengan tingkat pertumbuhan PDB riil. Margin NII diharapkan menurun pada saat pertumbuhan ekonomi yang lebih tinggi, karena bank memiliki peluang investasi yang lebih selama booming ekonomi, dan diharapkan dapat meningkatkan tarif deposito mereka untuk menarik lebih banyak dana yang diperlukan untuk membiayai proyek-proyek baru. Inflasi dinyatakan oleh perubahan persentase indeks CPI. Inflasi yang lebih tinggi menyebabkan ketidakpastian ekonomi dan diperkirakan akan memperlebar NIM.

\section{Determinan Institusional (I)}

Indeks institusional merupakan sebuah indeks gabungan dari tingkat perkembangan kelembagaan yang disusun oleh Kaufmann, et al. (2002). Corruptcont merupakan indeks yang digunakan untuk menangkap sejauh mana kekuasaan publik dimanfaatkan demi keuntungan pribadi. Sementara itu regqual, kualitas regulasi merupakan indeks yang menangkap persepsi dari pelaku usaha terhadap kemampuan pemerintah dalam merumuskan dan melaksanakan kebijakan dan regulasi yang sehat.

\section{Determinan Regulasi (R)}

$\mathrm{BI}$ rate adalah suku bunga kebijakan yang mencerminkan sikap kebijakan moneter yang ditetapkan oleh Bank Indonesia dan diumumkan kepada publik. Kebijakan ini diimplementasikan pada operasi moneter yang dilakukan Bank Indonesia melalui pengelolaan likuiditas (liquidity management) di pasar uang untuk mencapai sasaran operasional kebijakan moneter. Sasaran operasional kebijakan moneter dicerminkan pada perkembangan suku bunga Pasar Uang AntarBank Overnight (PUAB O/N). Pergerakan di suku bunga PUAB ini diharapkan akan diikuti oleh perkembangan di suku bunga deposito, dan pada gilirannya suku bunga kredit perbankan ${ }^{5}$.

\section{HASIL DAN PEMBAHASAN}

Bagian pertama menyajikan hasil utama untuk variabel bank tertentu menggunakan model panel Fixed Effect (FE) dengan tujuan untuk mengontrol karakteristik spesifik setiap perbankan. Bagian berikutnya membahas dampak struktur pasar dan

BI rate merupakan referensi perbankan dalam menentukan tingkat suku bunga. Sebagai referensi, maka diharapkan perbankan secara nasional akan menetapkan suku bunganya mengikuti ketentuan BI. Dengan mempertimbangkan pula faktor-faktor lain dalam perekonomian, Bank Indonesia pada umumnya akan menaikkan BI rate apabila inflasi ke depan diperkirakan melampaui sasaran yang telah ditetapkan. Sebaliknya Bank Indonesia akan menurunkan $\mathrm{BI}$ rate apabila inflasi ke depan diperkirakan berada di bawah sasaran yang telah ditetapkan (www.bi.go.id/id/ moneter/bi-rate/penjelasan /Contents/Default.aspx). variabel makroekonomi. Robustness test (tes kerigid-an) hasil temuan disajikan di bagian akhir.

\section{A. Hasil Dasar}

Gambar 3 menunjukkan perkembangan pola konsentrasi pasar sektor perbankan. Dari data terlihat bahwa konsentrasi pasar dari sisi aset dan kredit memang mengalami penurunan seiring waktu. Namun untuk konsentrasi pasar dari sisi loan rate (rasio pendapatan bunga yang dihasilkan dari loan) dan deprate (rasio biaya bunga dari pemeliharaan deposito/DPK) semakin membesar. Walapun trendnya mengalami penurunan dari tahun 2004 sampai puncaknya pada saat krisis global tahun 2008, namun setelah itu konsentrasinya meningkat secara perlahan namun pasti.

Ternyata industri perbankan Indonesia secara keseluruhan sampel mengalami kenaikan BOPO. $\mathrm{Hal}$ ini berpengaruh signifikan menurunkan NIM keseluruhan industri perbankan. Jika data dibreakdown pada jenis bank, maka magnitude penurunan terbesar terjadi pada bank BUMN. Hal ini terlihat dari koefisien pada semua kolom 7 pada Tabel 2, kolom 11 pada Tabel 3, kolom 15 pada Tabel 4 dan kolom 19 pada Tabel 5 pada bagian lampiran. Kondisi ini sesuai dengan teori bahwa bank yang lebih besar ukurannya, umumnya memiliki spread suku bunga lebih rendah dari bank-bank kecil, yang mencerminkan skala ekonomi.

Pada saat yang sama, pangsa pasar bank tersebut mengalami peningkatan terutama dari sisi aset dan pembiayaan. Dalam hal ini, 2 bank BUMN, yaitu Bank Mandiri dan BNI, merupakan 2 bank terbesar dari sisi aset. Sementara bank asing walaupun memiliki aset besar, namun pangsa pasar mereka masih satu tingkat di bawah bank BUMN. Hal ini mungkin disebabkan fakta bahwa kehadiran bank asing yang tergolong baru 2 pada dekade terakhir, masih mencari celah pasar baru untuk memperbesar pangsa pasarnya.

Hasil menarik pada Tabel 1 kolom 3 dan 4, terkait dua kutub perbankan, bank BUMN dan bank asing, memperlihatkan bahwa beberapa indikator terkait preferensi risiko, seperti risk averse dan risiko kredit (credit risk) kedua tipe bank ini, menunjukkan arah relasi yang berbeda pada NIM. Bagi bank BUMN, risk averse berelasi negatif kepada NIM. Sementara itu bagi bank asing, risk averse justru berelasi positif, sesuai dengan teori, dengan NIM. Hal ini menyiratkan bahwa, bank BUMN kurang memberi perhatian yang cukup kepada rasio ekuitas terhadap aset. Bank BUMN secara rerata diasumsikan memiliki rasio ekuitas yang cukup rendah sehingga terpaksa mematok NIM yang relatif lebih tinggi. Penjelasan ini sesuai dengan Gambar 1 pada bagian pendahuluan 


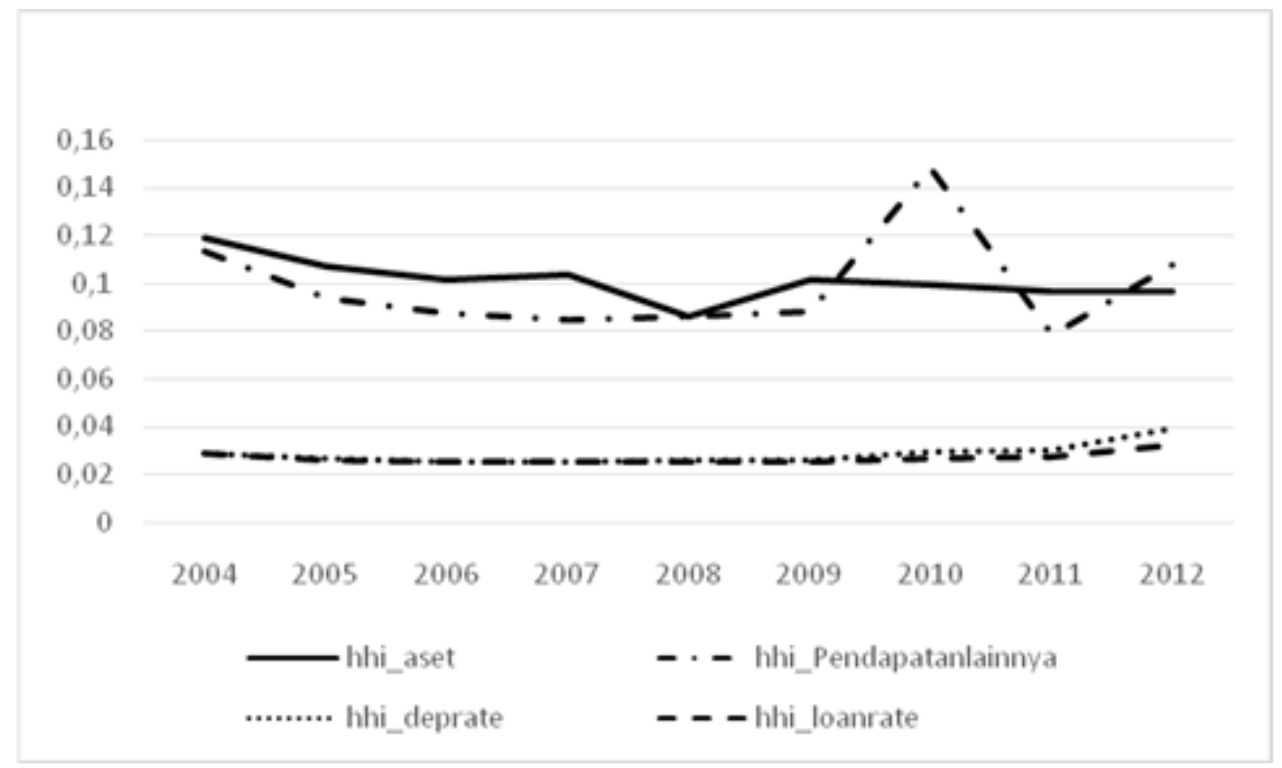

Sumber: Bank Indonesia dari berbagai tahun (diolah).

Gambar 3. Perkembangan Tingkat Konsentrasi Pasar

yang memperlihatkan bank BUMN memegang peringkat pertama dalam NIM.

Sebaliknya, bank asing memiliki rasio ekuitas yang lebih baik dan diprediksi akan lebih tahan terhadap shock kredit. Namun setidaknya, ada 2 catatan penting terhadap peran bank asing terhadap NIM perbankan nasional. Pertama, di tengah stagnannya pangsa pasar bank BUMN, bank asing mencatatkan perkembangan pangsa dengan trend menaik relatif stabil. Hal ini terlihat dari magnitude terbesar dari efek ukuran operasional (In_aset) bank asing terhadap NIM jenis perbankan lain dan angka rerata NIM perbankan nasional (Gambar 3). Kedua, konsekuensi dari ukuran operasional yang semakin membesar dari waktu ke waktu, bank asing mengalami peningkatan non-performing loan (NPL). Pada gilirannya hal itu akan dikompensasikan kepada peningkatan NIM (lihat pada Tabel 1 kolom 4 pada lampiran) ${ }^{6}$.

\section{B. Karakteristik Makro Ekonomi}

Selanjutnya dilakukan uji dampak dari konsentrasi bank pada NIM dengan mengontrol karakteristik perbankan dan inflasi (Tabel 3 Lampiran). Analisis tersendiri terhadap dampak tingkat inflasi (bukan fitur sektor ekonomi makro dan keuangan lainnya) dilakukan karena beberapa alasan (i) teori menunjukkan bahwa inflasi memengaruhi NIM, (ii) inflasi tetap bermakna dikaitkan dengan NIM ketika kontrol indikator makroekonomi dan keuangan lainnya ditambahkan, (iii) variabel keuangan makroekonomi sangat berkorelasi dan (iv) hasil yang sama akan diperoleh ketika menggunakan variabel makroekonomi lainnya.

\footnotetext{
$6 \quad$ Kolom 4 pada Tabel 2 pada halaman lampiran memperlihatkan relasi yang positif signifikan antara LDR dengan NIM pada bank asing dengan magnitude (koefisien) yang besar.
}

Hasil analisis menunjukkan bahwa inflasi berdampak negatif walaupun tidak signifikan dalam spesifikasi yang berbeda pada Tabel 2 di bagian lampiran. Beberapa jenis bank agaknya rentan terhadap fluktuasi inflasi yang terjadi. Hal ini terlihat bahwa bank swasta yang semula dampak ukuran operasionalnya menurunkan NIM secara signifikan, ketika variabel inflasi dimasukkan mengalami penurunan performa. Dampak ukuran perbankan yang semula negatif terhadap NIM secara signifikan, kemudian signifikansi dampaknya menjadi hilang. Agaknya perlambatan ini bersumber dari 2 hal. Pertama, menyusutnya pertumbuhan permintaan kredit yang terlihat dari efek penurunan pendapatan per kapita riil (Ingdprc) yang signifikan negatif terhadap NIM. Penyebab pertama ini juga dirasakan oleh bank BUMN secara signifikan.

Kedua, berasal dari kenaikan harga input yang menggerogoti profitabiltas perbankan. Dalam konteks ini, suku bunga perbankan juga harus meningkat seiring laju inflasi. Namun kedua penyebab ini tidak dirasakan dampaknya oleh perbankan asing sama sekali. Secara implisit bisa diduga bahwa bank asing yang ada merupakan perusahaan MNC yang sudah terlebih dahulu mendiferensiasi market share-nya dengan pasar luar negeri. Dalam konteks sedikit berbeda, temuan ini sesuai dengan hasil studi yang dilakukan Poghosyan (2010) pada 11 negara terkategori emerging market di mana level kehadiran perbankan asing sangat tinggi. Studi pada negara di Eropa Timur dan Tengah Studi, Central and Eastern European countries (CEECS), tidak menemukan dampak penurunan NIM pada industri perbankan negara tuan rumah. 


\section{Karakteristik Institusi dan Regulasi}

Tabel 3 Lampiran menunjukkan variasi dampak variabel kelembagaan dan regulasi terhadap variasi NIM ketika faktor-faktor determinan spesifik milik bank dan konsentrasi pasar dikontrol. Hasil ini mendokumentasikan hubungan yang kuat antara karakteristik kelembagaan dan NIM. Berbagai penelitian menyebutkan bahwa negara dengan kualitas kelembagaan dan regulasi yang lebih kondusif cenderung mendorong NIM menjadi relatif lebih rendah dibandingkan negara yang memiliki regulasi yang lebih buruk (Barajas, et al., 2000). Indikator pengendalian korupsi dan kualitas peraturan ternyata memiliki dampak negatif dan signifikan terhadap margin perbankan swasta dan nasional secara keseluruhan.

Menariknya, dampak pangsa pasar ternyata menjadi tidak signifikan ketika salah satu variabel kelembagaan dimasukkan ke dalam spesifikasi. Pengukuran dampak ukuran dari perbankan, dengan mengontrol karakteristik spesifik lainnya dari bank, variabel makroekonomi seperti inflasi, variable regulasi seperti kualitas insitusi dan level korupsi, secara bersamaan menemukan fakta bahwa variabel regulasi walaupun secara umum tetap berelasi negatif dengan NIM, namun tidak memberikan kekuatan penjelas tambahan.

Lebih menarik lagi, dampak regulasi dalam hal ini $\mathrm{Bl}$ rate ternyata memang tidak (signifikan) memengaruhi NIM. Ketika dijabarkan lebih detail, peranan $\mathrm{BI}$ rate juga ambigu terhadap NIM perbankan. Dampak BI rate terhadap NIM perbankan BUMN adalah negatif, sementara terhadap NIM perbankan lain justru positif. Agaknya struktur pendapatan dan biaya perbankan BUMN relatif lebih tidak sensitif terhadap level $\mathrm{BI}$ rate dibandingkan perbankan lainnya. Hal ini bisa diinterpretasikan sebagai alarm bahaya dampak buruk dari besarnya ukuran perbankan BUMN yang membuat mereka kurang gesit dan responsif menyikapi BI rate.

\section{Robustness Check}

Tulisan ini juga menggunakan sejumlah pengujian ke-rigid-an (robustness test) dari temuan utama. Tujuan dari uji ini adalah untuk lebih mengeksplorasi apakah hubungan negatif antara overhead cost dan ukuran operasional perbankan dengan margin bunga tidak akan berubah (rigid) ketika menggunakan berbagai definisi yang berbeda dari ukuran operasional dan memperbarui jumlah sampel. Pertama, mengganti ukuran operasional perbankan dari sisi aset dengan ukuran dari sisi kredit (loan). Hal ini dapat dilihat pada Tabel 4 Lampiran. Tidak seperti aset, pembiayaan/kredit (loan) mengandung risiko besar bagi perbankan. Risiko kredit yang besar akan memaksa bank untuk menaikkan NIM. Pada akhirnya, dampak hal ini adalah ambigu. Hasil ini mengkonfirmasi temuan sebelumnya, besaran ukuran sisi kredit ketika dimasukkan ke dalam spesifikasi memiliki koefisien negatif yang sangat signifikan.

Menariknya dampak secara nasional pada industri perbankan dari mengganti ukuran operasional bank dengan ukuran tertentu serta merta juga memengaruhi hasil utama untuk variabel lain. Signifikansi pola relasi yang negatif antara beberapa variabel makro seperti inflasi dan pendapatan riil per kapita dengan NIM, menjadi hilang. Sementara indeks kelembagaan dan kontrol terhadap korupsi, tetap signifikan negatif. Patut dicatat bahwa pentingnya ukuran operasional tidak lenyap dalam spesifikasi dengan variabel institusional, menandakan pentingnya ukuran operasional perbankan terhadap NIM.

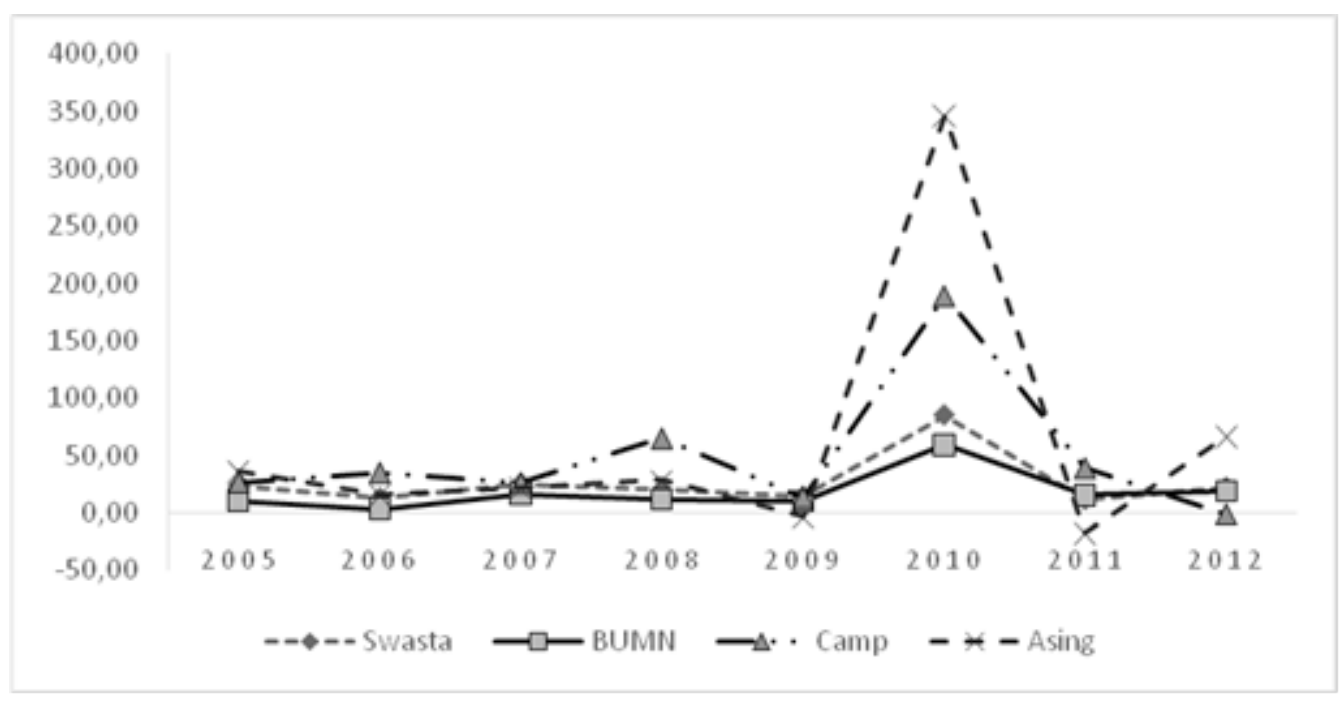

Sumber: Bank Indonesia dari berbagai tahun (diolah).

Gambar 4. Perkembangan Tingkat Overhead Cost 
Kedua, menggunakan variabel total kredit untuk menghitung konsentrasi pasar, bukan lagi total aset. Variabel ini merupakan proksi alternatif dari konsentrasi pasar yang sangat relevan untuk LICs, di mana bank-bank cenderung tidak sepenuhnya terlibat dalam kegiatan intermediasi keuangan dan hubungan antara total aset dan pinjaman serta deposito nyaris tidak sejalan. Misalnya, beberapa bank di negara LICs sangat terlibat dalam pembiayaan utang pemerintah, yang merupakan bagian besar dari aset bank. Akibatnya, peningkatan aset bank belum tentu mengarah pada ekspansi kredit. Demikian pula, beberapa bank sangat bergantung pada deposito pemerintah sebagai sumber pendanaan, yang mendistorsi hubungan antara total kewajiban dan simpanan nasabah.

Tabel 5 Lampiran menunjukkan hasil laporan dari spesifikasi dengan total kredit sebagai ukuran konsentrasi pasar masing-masing bank. Estimasi menunjukkan bahwa secara nasional, koefisien relasi antara ukuran konsentrasi pasar dengan NIM tetap positif secara signifikan. Hasil ini mengkonfirmasi temuan utama bahwa NIM cenderung lebih besar pada negara-negara dengan struktur pasar industri perbankan yang lebih terkonsentrasi, terlepas dari apakah konsentrasi diukur pada sisi aktiva atau kewajiban.

\section{SIMPULAN DAN SARAN}

Dalam tulisan ini, dataset panel bank digunakan untuk menentukan faktor-faktor penentu NIM industri perbankan di Indonesia selama periode tahun 2004-2012. Hasil analisis menunjukkan bukti bahwa karakteristik bank tertentu dan struktur pasar berperan penting dalam menjelaskan variasi NIM.

\section{A. Simpulan}

Pertama, karakteristik individual bank menjelaskan bagian penting dari variasi dalam biaya intermediasi keuangan. NIM yang tinggi dan biaya overhead yang besar cenderung berkaitan dengan ukuran bank-bank kecil, bank yang memegang sebagian kecil aset likuid, bank yang memegang jumlah modal yang relatif rendah, bank tanpa penghasilan besar dari kegiatan berbasis biaya dan bank dengan pangsa pasar yang besar.

Kedua, regulasi dan kualitas institusi ternyata tidak cukup membantu menjelaskan variasi biaya intermediasi keuangan. Temuan ini tidak berubah walaupun setelah mengontrol variabel konsentrasi sektor perbankan, karakteristik bank dan tingkat inflasi. Temuan ini memang berbeda jauh dengan teori efisiensi dalam perbankan yang established. Namun temuan ini sejalan dengan hasil penelitian yang dilakukan oleh Demirguc-Kunt, Laeven dan
Levine, (2004). Hal ini setidaknya bisa dijelaskan dengan 2 hal. Pertama, level regulasi perbankan Indonesia yang justru sudah pada standar maksimum ${ }^{7}$. Kedua, memang indikator regulasi tidak bisa dipandang terisolasi dari struktur hak kepemilikan dan kompetisi yang sudah terbangun dalam dunia perbankan sebelumnya. ${ }^{8}$

Ketiga, hubungan antara beberapa ukuran seperti NPL dengan NIM adalah ambigu, yang mungkin mengejutkan karena prediksi yang bertentangan dari teori. Ketika dikontrol dengan karakteristik spesifik lainnya dari bank, secara umum NPL berelasi negatif walaupun tidak signifikan dengan NIM. Hubungan ini menjadi berubah ketika memasukkan variabel regulasi bank dan makroekonomi.

Keempat, hasil studi menunjukkan bahwa kehadiran perbankan asing selevel MNC, ternyata tidak berdampak cukup terhadap penurunan biaya intermediasi (NIM) perbankan nasional secara umum. Hal ini terlihat bahwa walaupun perbankan asing memiliki aset yang besar, namun ketika terjadi shock inflasi, maka relasi negatif ukuran perbankan secara nasional melemah taraf signifikansinya.

\section{B. Saran}

Mahalnya biaya intermediasi keuangan sektor perbankan atau masih rendahnya efisiensi sektor perbankan Indonesia menunjukkan bahwa masih ada ruang untuk konsolidasi, rasionalisasi biaya dan ukuran dan pemanfaatan kemajuan teknologi. Konsolidasi sektor perbankan bagaimanapun juga harus dilanjutkan melalui mekanisme pasar yang didorong melalui langkah-langkah regulasi, seperti kenaikan lebih lanjut dalam persyaratan modal minimum.

Lebih lanjut, sebuah kebijakan persaingan yang sukses harus bertujuan untuk mengurangi segmentasi pasar, meningkatkan transparansi dan menciptakan lapangan persaingan yang adil dan sehat untuk semua pelaku pasar. Mempromosikan persaingan perbankan yang lebih sehat harus menjadi target utama dari regulator dengan secara khusus meningkatkan transparansi dan keterbukaan pada produk perbankan.

Satu hal penting lainnya adalah perlunya perbaikan terhadap kerentanan industri perbankan nasional oleh shock yang ditransmisikan dari sektor

\footnotetext{
Bahkan dari sisi kebebasan kepemilikan, perbankan Indonesia pada rejim tahun 2012 sudah tergolong paling liberal. Pemerintah mengijinkan kepemilikan Bank oleh asing sampai 90 persen, dibandingkan dengan regulasi kepemilikan perbankan di negara tetangga, seperti Malaysia dan Singapura.

8 Hal ini dapat dibaca lebih jauh dalam penelitian Levine, et al., 2004
} 
lain, baik terkait kondisi ekonomi seperti inflasi maupun nonekonomi seperti regulasi, terutama terkait kehadiran bank asing. Paling tidak, dapat dikatakan bahwa perbankan nasional masih belum berhasil mengambil pelajaran bagaimana me-manage risiko (management portfolio) dari kompetitornya, perbankan asing.

Oleh karenanya dalam hal ini, penyusunan suatu kebijakan oleh regulator juga harus mempertimbangkan kondisi struktur pasar, struktur biaya dan pendapatan perbankan dan bauran regulasi dan makroekonomi yang memengaruhinya secara mendetil. Semua kompleksitas permasalahan ini menuntut kualifikasi regulator yang tinggi. Regulator dituntut harus memahami perilaku perbankan sesuai karakteristik individu dan usaha mereka masingmasing.

\section{DAFTAR PUSTAKA}

\section{Jurnal}

Allen, L. (1988). The determinants of bank interest margins: A Note. Journal of Financial and Quantitative Analysis, 23(2), 231-35.

Angbazo, L. (1997). Commercial bank net interest margins, default risk, interest-rate risk and offbalance sheet banking. Journal of Banking and Finance, 21, 55-87.

Barajas, A., Steiner, R., and Salazar, N. (2000). The impact of liberalization and foreign investment in Colombia's financial sector. Journal of Development Economics, 63(1), 157-96.

Beck, T., Demirguc-Kunt, A., and Levine, R. (2000). A new database on financial development and structure. World Bank Economic Review, 597605.

Brock, P., and Rojas-Suarez, L. (2000). Understanding the behavior of bank spreads in Latin America. Journal of Development Economics, 63(1), 113-134.

Claessens, S., Demirguc-Kunt, A. and Huizinga, $\mathrm{H}$. (2001). How does foreign entry affect domestic banking markets?. Journal of Banking and Finance, 25, 891-911.

Demirguc-Kunt, A., Laeven, L., and Levine, R. (2004). Regulations, market structure, institutions, and the cost of financial intermediation. Journal of Money, Credit, and Banking, 36(3), 593-622.
Ho, T. and Saunders, A. (1981). The determinants of bank interest margins: Theory and empirical evidence. Journal of Financial and Quantitative Analysis, XVI(4), 581-600.

Jayaratne, J. and Strahan, P. (1996). The financegrowth nexus: Evidence from bank branch deregulation. Quarterly Journal of Economics, $111,639-670$.

Maudos, J. and Fernandez de Guevara, J. (2004). Factors explaining the interest margin in the banking sectors of the European Union. Journal of Banking and Finance, 28, 2.259-2.281.

Neumark, D. and Sharpe, S. A. (1992). Market structure and the nature of price rigidity: Evidence from the market for consumer deposits. Quarterly Journal of Economics, 107, 657-680.

Peltzman, S. (1977). The gains and losses from industrial concentration. Journal of Law and Economics, 20, 229-263.

Petersen, M. A. and Rajan, R. G. (1995). The effect of credit market competition on lending relationships. Quarterly Journal of Economics, 110, 407-443.

Poghosyan, T. (2010). Re-Examining the impact of foreign bank participation on interest margins in emerging markets. Emerging Markets Review, 11(4), 390-403.

Rajan, R. G., and Zingales, L. (1998). Financial dependence and growth. American Economic Review, 88, 559-586.

\section{Working Paper}

Kaufmann, D., Kraay, A., and Zoido-Lobaton, P. (2002). Governance matters II: Updated indicators for 2000/01. World Bank Policy Research Working Paper No. 2772. Washington, World Bank.

Randall, R. (1998). Interest rate spreads in the Eastern Caribbean. IMF Working Paper, 98/59 Washington, International Monetary Fund.

\section{Makalah}

Moyo, J., Nandwa, B., Oduor, J., and Simpasa, A. (2014). Financial sector reforms, competition and banking system stability in Sub-Sahara Africa, Paper dipresentasikan pada The IMF/ DFID Conference on Macroeconomic Challenged Facing Low-Income countries. International Monetary Fund, Washington DC, January 30-31, 2014. 
Sumber Digital

ADB. (2015). Economic and financial indicators, diperoleh tanggal 15 November 2015, dari https://aric.adb.org/macroindicators.

Bank Indonesia. (2015). Penjelasan BI Rate sebagai suku bunga acuan, diperoleh tanggal 27 November 2015, dari http://www.bi.go.id/id/ moneter/ bi-rate/penjelasan/Contents/Default. aspx.
OECD. (2015), OECD economic surveys 2015 Indonesia March 2015 overview, diperoleh tanggal 15 November 2015, dari https://www. oecd.org/eco/surveys/Overviw-Indonesia-2015. pdf. 
LAMPIRAN 1. Statistic Descriptive

\begin{tabular}{|c|c|c|c|c|c|}
\hline NIM & 378 & 0,0885608 & 0,0369171 & 0,0211573 & 0,2870382 \\
\hline BOPO & 378 & 0,8098771 & 0,8264691 & 0,2574365 & 16,41217 \\
\hline sizeops1 & 378 & 16,10958 & 1,936207 & 11,64408 & 20,14552 \\
\hline sizeops2 & 378 & 15,56865 & 1,95385 & 10,75351 & 19,66758 \\
\hline riskaver & 378 & 0,1429469 & 0,0930958 & $-0,0007262$ & 0,5162611 \\
\hline NPL & 378 & 0,0348713 & 0,0503503 & 0 & 0,8176113 \\
\hline LDR & 378 & 1,594388 & 1,144637 & 0,1103595 & 15,47424 \\
\hline credrisk & 378 & 0,2269044 & 0,422629 & 0,0002105 & 5,780363 \\
\hline MCaset & 378 & 0,1009635 & 0,0084036 & 0,0858641 & 0,1188065 \\
\hline MCloan & 378 & 0,0911515 & 0,0035155 & 0,086828 & 0,0989775 \\
\hline inf & 378 & 7,285802 & 2,900288 & 4,279512 & 13,10942 \\
\hline Ingdprc & 378 & $-4,827119$ & 0,1171367 & $-5,005742$ & $-4,638317$ \\
\hline Inexc & 378 & 9,143659 & 0,0495516 & 9,079593 & 9,250106 \\
\hline BIrate & 378 & 8,21875 & 2,146982 & 5,77 & 12,75 \\
\hline regqual & 378 & $-0,3911111$ & 0,1214909 & $-0,67$ & $-0,28$ \\
\hline corruptcont & 378 & $-0,7344444$ & 0,1136906 & $-0,89$ & $-0,56$ \\
\hline
\end{tabular}


LAMPIRAN 2. Uji Hausman (Model Dasar)

* KESELURUHAN DATA PERBANKAN (GABUNGAN) qui xtreg nim bopo sizeops riskaver $\mathrm{npl}$ ldr credrisk MCaset, fe . estimate store fix

- qui xtreg nim bopo sizeops riskaver npl Idr credrisk MCaset, re . hausman fix

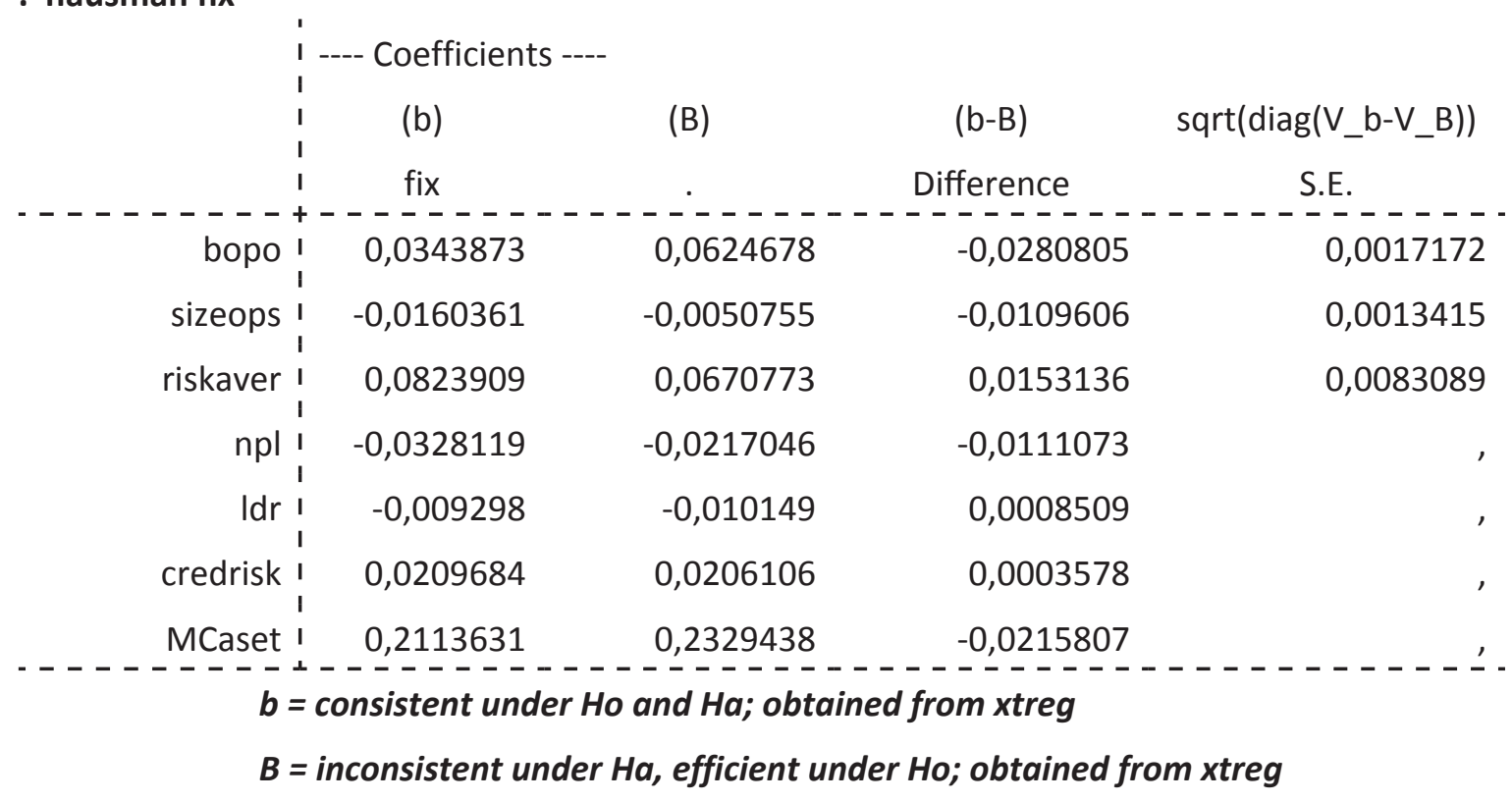

Uji: $\quad$ Ho: difference in coefficients not systematic

$$
\begin{aligned}
\operatorname{chi} 2(7) & =(b-B)^{\prime}\left[\left(V_{-} b-V_{-} B\right)^{\wedge}(-1)\right](b-B) \\
& =53,93
\end{aligned}
$$

Prob $>$ chi2 $=0,0000$

(V_b-V_B is not positive definite) 


\section{* DATA PERBANKAN SWASTA NASIONAL}

- qui xtreg nim bopo sizeops riskaver $n p l$ ldr credrisk MCaset if Swasta==1, fe

. estimate store fix

. qui xtreg nim bopo sizeops riskaver $\mathrm{npl}$ Idr credrisk MCaset if Swasta==1, re

. hausman fix

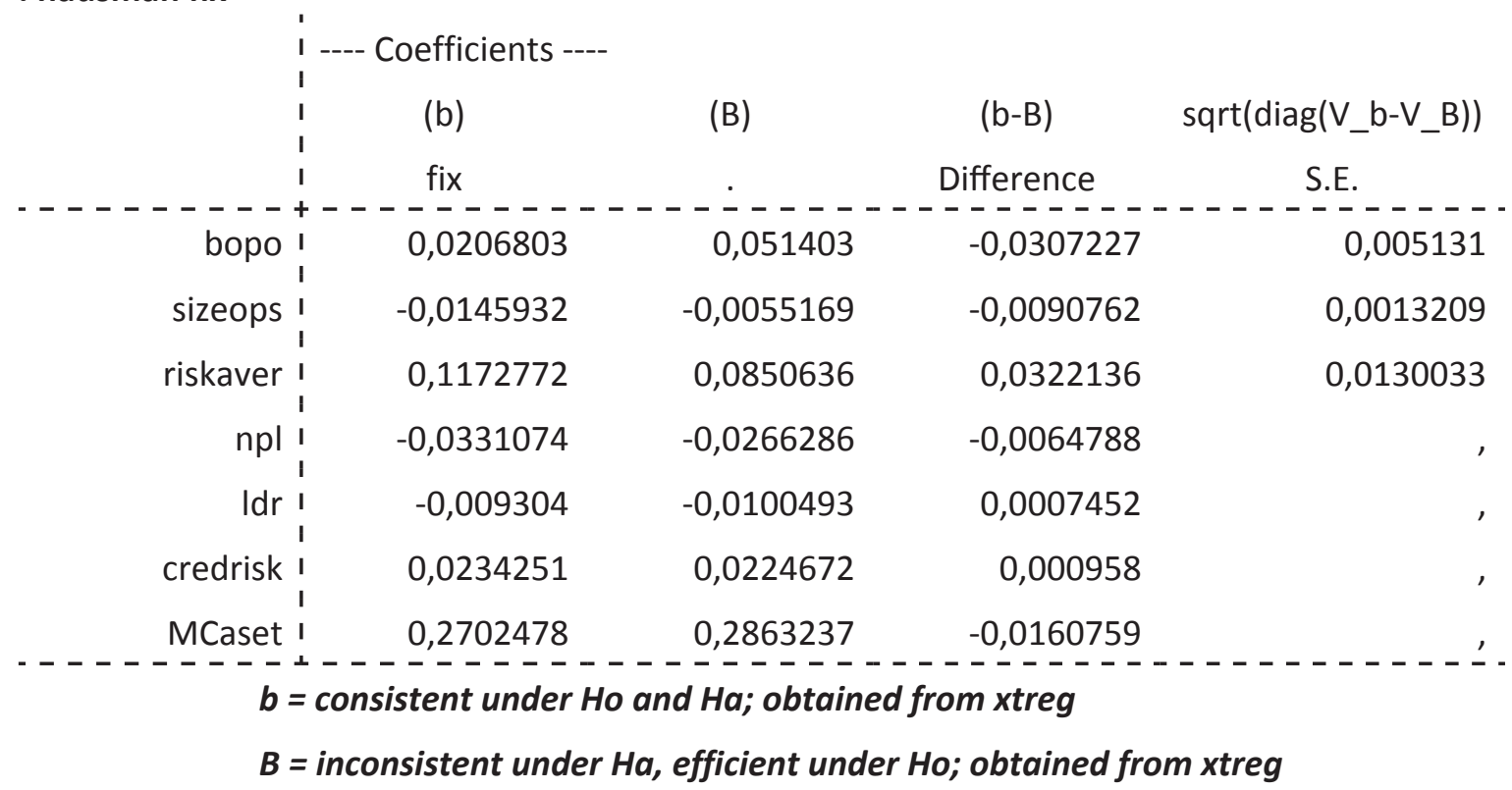

Uji: $\quad$ Ho: difference in coefficients not systematic

$$
\begin{aligned}
& \operatorname{chi2}(7)=(\mathrm{b}-\mathrm{B})^{\prime}\left[\left(\mathrm{V} \_\mathrm{b}-\mathrm{V} \_\mathrm{B}\right)^{\wedge}(-1)\right](\mathrm{b}-\mathrm{B}) \\
&=25,79 \\
& \text { Prob }>\text { chi2 }=0,0006 \\
&\left(\mathrm{~V} \_\mathrm{b}-\mathrm{V} \_\mathrm{B} \text { is not positive definite }\right)
\end{aligned}
$$




\section{* DATA PERBANKAN BUMN}

- qui xtreg nim bopo sizeops riskaver npl ldr credrisk MCaset if $B U M N==1$, fe

. estimate store fix

. qui xtreg nim bopo sizeops riskaver $\mathrm{npl}$ Idr credrisk MCaset if $B U M N==1$, re

. hausman fix

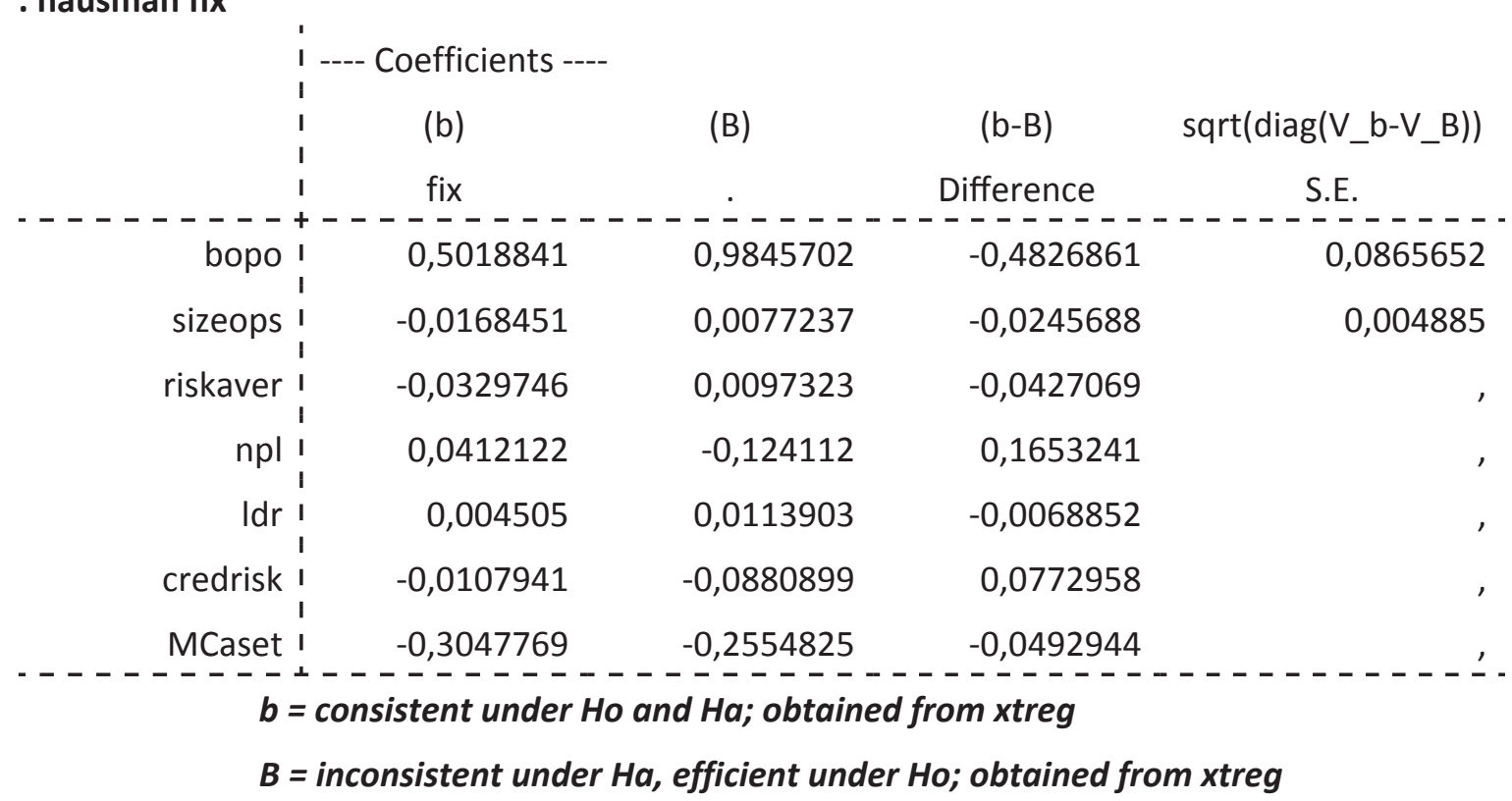

Uji: $\quad$ Ho: difference in coefficients not systematic

$$
\begin{aligned}
& \operatorname{chi2}(7)=(b-B)^{\prime}\left[\left(V_{-} b-V_{-} B\right)^{\wedge}(-1)\right](b-B) \\
& =6,44 \\
& \text { Prob }>\text { chi2 }=0,4890 \\
& \text { (V_b-V_B is not positive definite) }
\end{aligned}
$$


* DATA PERBANKAN CAMPURAN

- qui xtreg nim bopo sizeops riskaver npl Idr credrisk MCaset if Camp==1, fe

. estimate store fix

. qui xtreg nim bopo sizeops riskaver $\mathrm{npl}$ Idr credrisk MCaset if Camp==1, re

. hausman fix

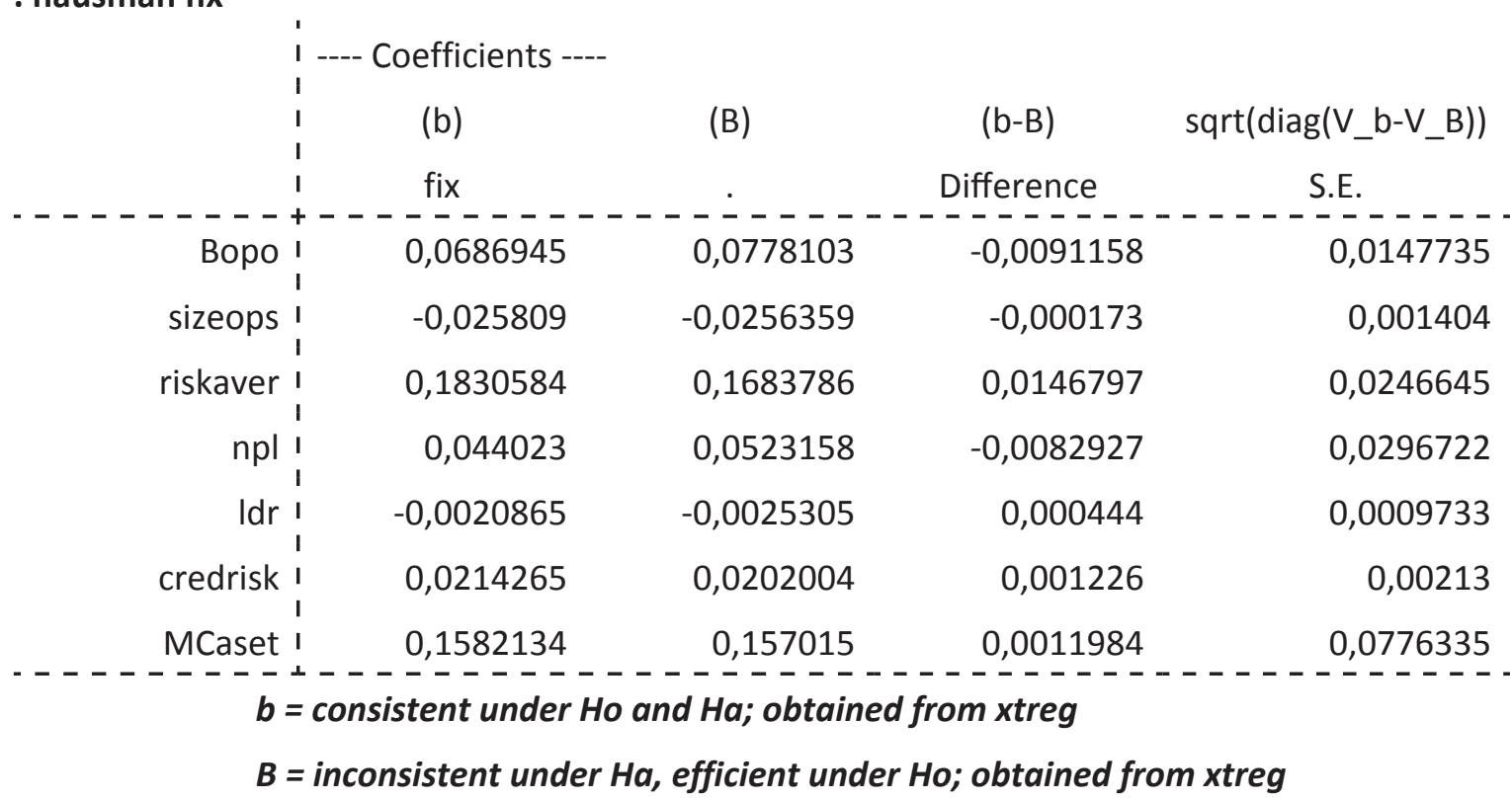

Uji: $\quad$ Ho: difference in coefficients not systematic

$$
\begin{aligned}
\operatorname{chi2}(7) & =(b-B)^{\prime}\left[\left(V_{-} b-V_{-} B\right)^{\wedge}(-1)\right](b-B) \\
& =0,72
\end{aligned}
$$

Prob $>$ chi2 $=0,9982$ 


\section{* DATA PERBANKAN ASING}

. qui xtreg nim bopo sizeops riskaver npl Idr credrisk MCaset if Asing==1, fe

. estimate store fix

. qui xtreg nim bopo sizeops riskaver $\mathrm{npl}$ Idr credrisk MCaset if Asing==1, re

. hausman fix

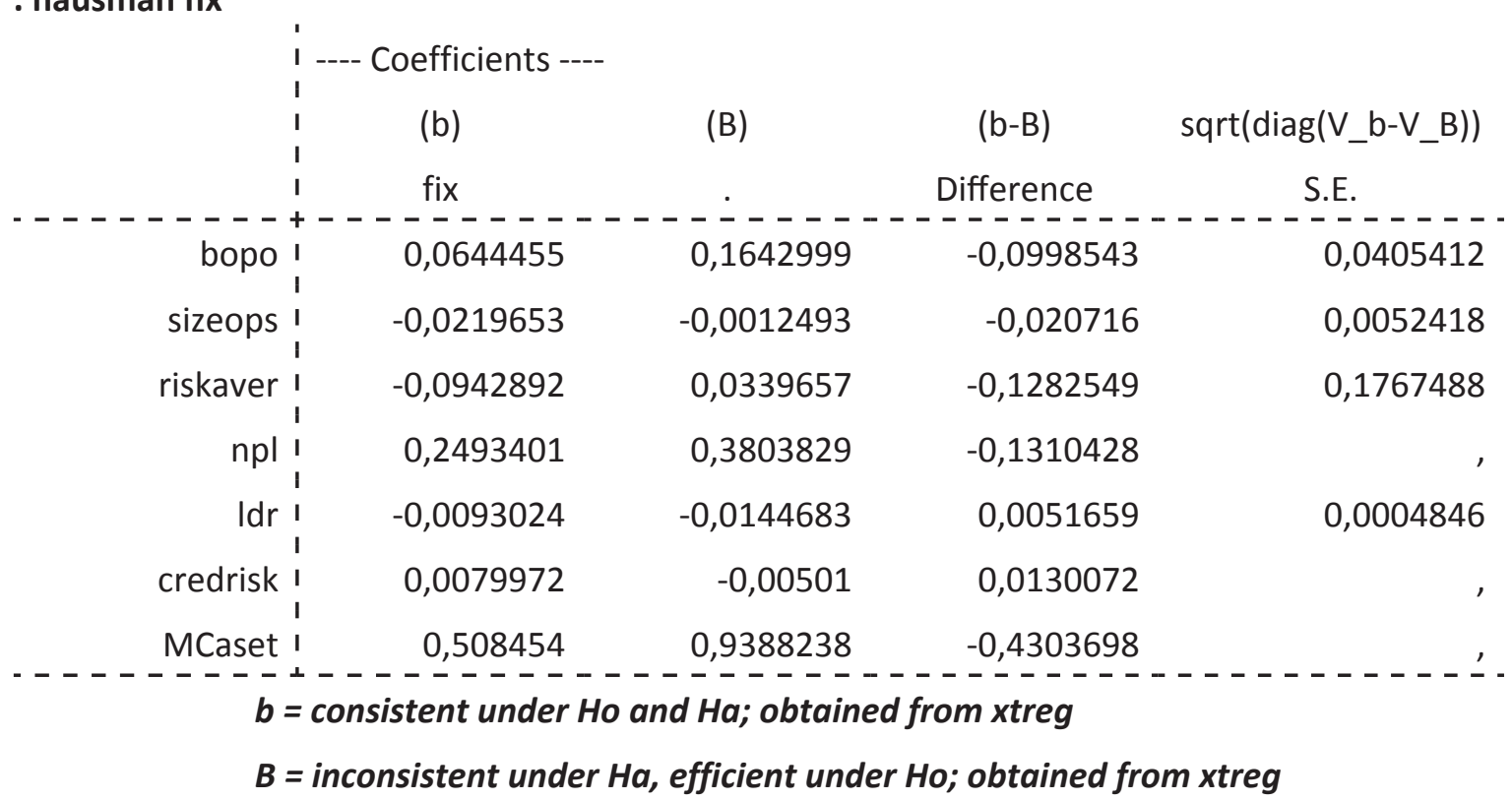

Uji: $\quad$ Ho: difference in coefficients not systematic

$$
\begin{aligned}
& \operatorname{chi2}(7)=(\mathrm{b}-\mathrm{B})^{\prime}\left[\left(\mathrm{V}_{-} \mathrm{b}-\mathrm{V} \_\mathrm{B}\right)^{\wedge}(-1)\right](\mathrm{b}-\mathrm{B}) \\
&=37,04 \\
& \text { Prob }>\text { chi2 }=0,0000 \\
&\left(\mathrm{~V} \_\mathrm{b}-\mathrm{V} \_\mathrm{B} \text { is not positive definite }\right)
\end{aligned}
$$




\section{LAMPIRAN 3.}

Tabel 1. Hasil Estimasi dengan Kontrol Karakteristik Spesifik Bank

\begin{tabular}{|c|c|c|c|c|}
\hline & (1) & (2) & (3) & $\begin{array}{c}\text { (4) } \\
\text { cino }\end{array}$ \\
\hline bopo & $-0,00721^{* *}$ & $-0,00683^{* *}$ & --0.0633 & $-\frac{A}{-0.0102 *}$ \\
\hline & $(-3,10)$ & $(-2,84)$ & $(-1,18)$ & $(-2,09)$ \\
\hline sizeops & $-0,0174 * * *$ & $-0,0158 * * *$ & $-0,0321 * * *$ & $-0,0334 * *$ \\
\hline & $(-8,31)$ & $(-7,12)$ & $(-6,24)$ & $(-3,12)$ \\
\hline riskaver & $0,0813 * *$ & $0,112 * * *$ & $-0,0568$ & 0,0199 \\
\hline & $(3,22)$ & $(3,85)$ & $(-1,85)$ & $(0,11)$ \\
\hline $\mathrm{npl}$ & $-0,00940$ & $-0,0162$ & 0,138 & $0,254^{*}$ \\
\hline & $(-0,37)$ & $(-0,61)$ & $(1,54)$ & $(2,29)$ \\
\hline Idr & $-0,00293$ & $-0,00353$ & $-0,00340$ & 0,00211 \\
\hline & $(-1,39)$ & $(-1,60)$ & $(-0,46)$ & $(0,43)$ \\
\hline credrisk & $0,0260 * * *$ & $0,0269 * * *$ & 0,0373 & 0,00175 \\
\hline & $(8,49)$ & $(8,52)$ & $(1,51)$ & $(0,09)$ \\
\hline MCaset & 0,234 & $0,292 *$ & $-0,362$ & 0,512 \\
\hline & $(1,83)$ & $(2,15)$ & $(-1,39)$ & $(1,08)$ \\
\hline $\mathrm{N}$ & 378 & 342 & 36 & 45 \\
\hline adj. R-sq & 0,362 & 0,372 & 0,625 & 0,491 \\
\hline
\end{tabular}

Keterangan: nilai t-stat berada dalam kurung.

$*: p<0,05, * *: p<0,01$, dan $* * *: p<0,001$ 
Tabel 2. Hasil Estimasi dengan Kontrol Karakteristik Makroekonomi

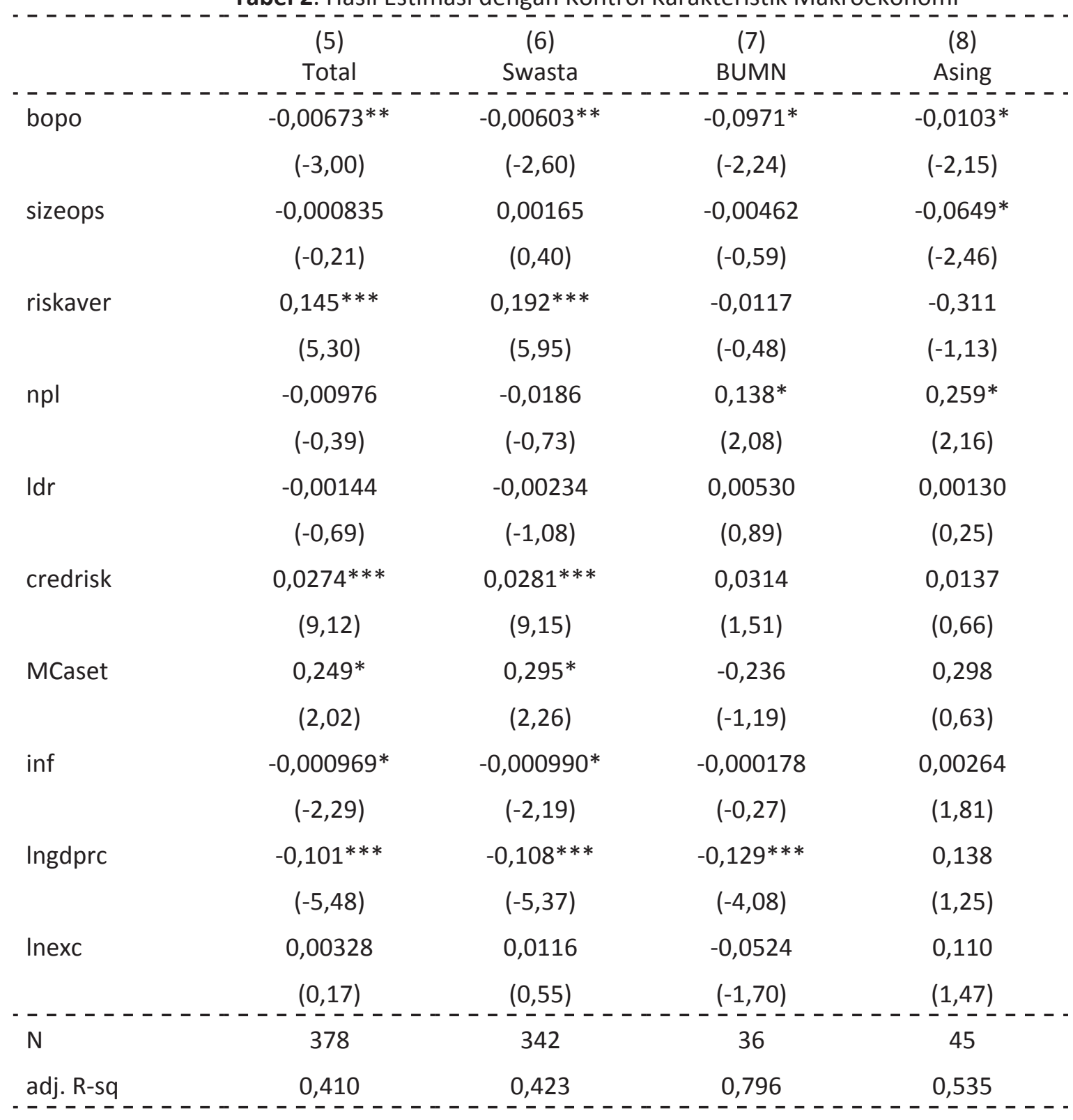

Keterangan: nilai t-stat berada dalam kurung.

$$
*: p<0,05, * *: p<0,01, \text { dan } * * *: p<0,001
$$


Tabel 3. Hasil Estimasi dengan Kontrol Karakteristik Institusi dan Regulasi

\begin{tabular}{|c|c|c|c|c|}
\hline & (9) & (10) & (11) & $(12)$ \\
\hline & & Swasta & BUMN & Asing \\
\hline bopo & $-0,00658^{* *}$ & $-0,00597 * *$ & $-0,160 * *$ & $-0,0131 * *$ \\
\hline & $(-3,02)$ & $(-2,63)$ & $(-3,38)$ & $(-3,16)$ \\
\hline sizeops & $-0,00263$ & $-0,000662$ & $-0,00950$ & $-0,0829 * *$ \\
\hline & $(-0,63)$ & $(-0,15)$ & $(-1,13)$ & $(-3,53)$ \\
\hline riskaver & $0,122 * * *$ & $0,163 * * *$ & $-0,0207$ & $-0,434$ \\
\hline & $(4,45)$ & $(4,85)$ & $(-0,84)$ & $(-1,90)$ \\
\hline $\mathrm{npl}$ & 0,0241 & 0,0152 & 0,135 & $0,252^{*}$ \\
\hline & $(0,99)$ & $(0,60)$ & $(2,12)$ & $(2,23)$ \\
\hline Idr & $-0,00171$ & $-0,00246$ & 0,00435 & 0,00411 \\
\hline & $(-0,82)$ & $(-1,13)$ & $(0,73)$ & $(0,90)$ \\
\hline credrisk & $0,0167 * * *$ & $0,0168 * * *$ & $-0,00882$ & 0,0113 \\
\hline & $(3,80)$ & $(3,70)$ & $(-0,37)$ & $(0,63)$ \\
\hline MCaset & $0,292^{*}$ & $0,335^{*}$ & $-0,180$ & 0,366 \\
\hline & $(2,38)$ & $(2,55)$ & $(-1,03)$ & $(0,90)$ \\
\hline inf & $-0,00192$ & $-0,00192$ & 0,000391 & $-0,00207$ \\
\hline & $(-1,67)$ & $(-1,55)$ & $(0,23)$ & $(-0,65)$ \\
\hline Ingdprc & $-0,0870 * *$ & $-0,0908 * *$ & $-0,0752$ & 0,0521 \\
\hline & $(-3,06)$ & $(-2,99)$ & $(-1,50)$ & $(0,43)$ \\
\hline Inexc & $-0,0284$ & $-0,0190$ & $-0,106^{*}$ & $-0,00874$ \\
\hline & $(-0,90)$ & $(-0,56)$ & $(-2,38)$ & $(-0,09)$ \\
\hline Blrate & 0,00297 & 0,00294 & $-0,00143$ & 0,00437 \\
\hline & $(1,07)$ & $(0,98)$ & $(-0,33)$ & $(0,57)$ \\
\hline regqual & 0,0989* & 0,0959 & $-0,0530$ & 0,163 \\
\hline & $(2,02)$ & $(1,82)$ & $(-0,66)$ & $(1,24)$ \\
\hline corruptcont & $-0,0419 *$ & $-0,0409 *$ & $-0,0425$ & $-0,0402$ \\
\hline & $(-2,42)$ & $(-2,20)$ & $(-1,74)$ & $(-0,85)$ \\
\hline$N$ & 336 & 304 & 32 & 40 \\
\hline adj. R-sq & 0,273 & 0,280 & 0,783 & 0,716 \\
\hline
\end{tabular}

Keterangan: nilai t-stat berada dalam kurung.

$*: p<0,05, * *: p<0,01$, dan $* * *: p<0,001$ 
Tabel 4. Robustness Check dengan Loan sebagai Ukuran Operasional

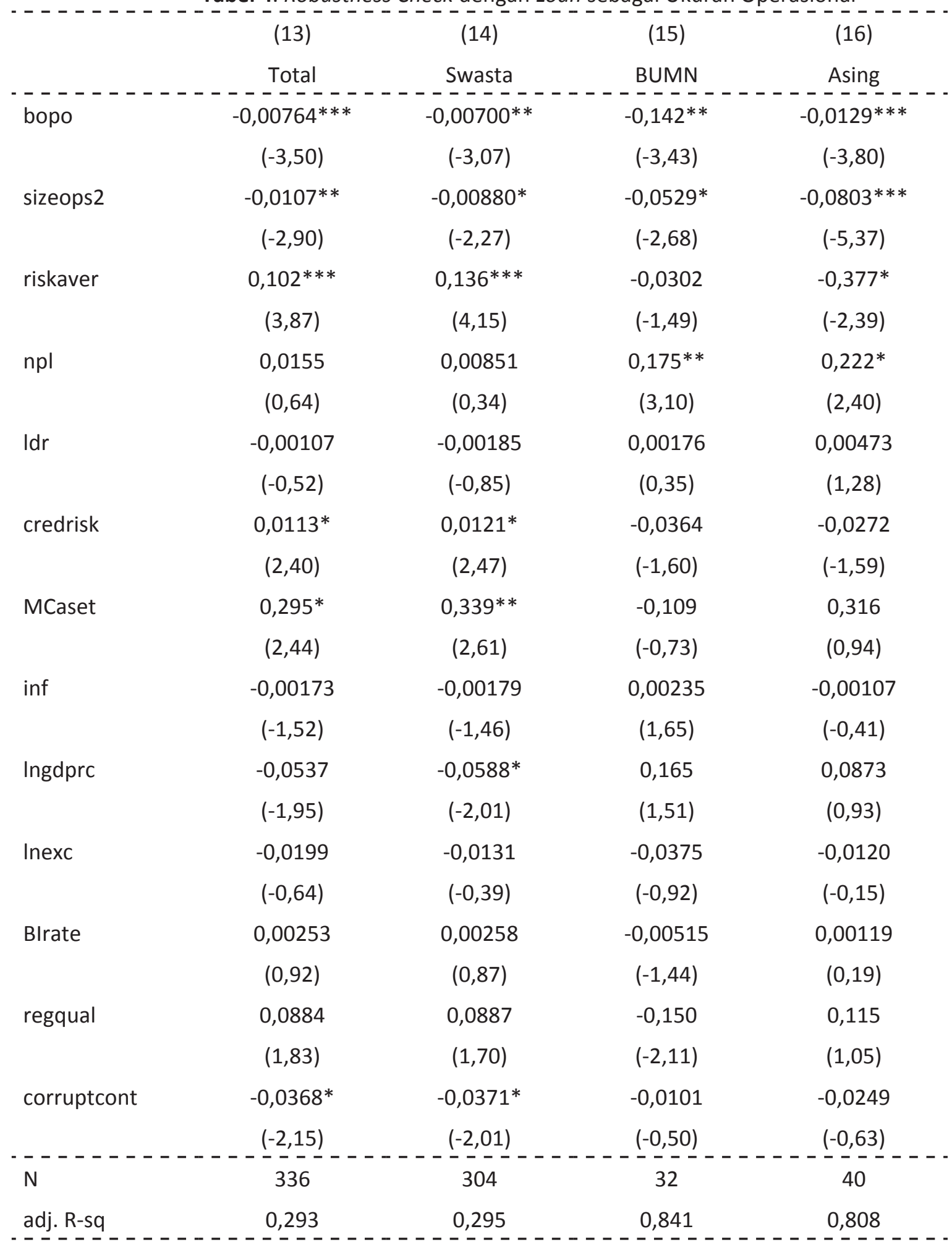

Keterangan: nilai t-stat berada dalam kurung.

$*: p<0,05, * *: p<0,01$, dan $* * *: p<0,001$ 
Tabel 5. Robustness Check dengan Loan sebagai Market Concentration

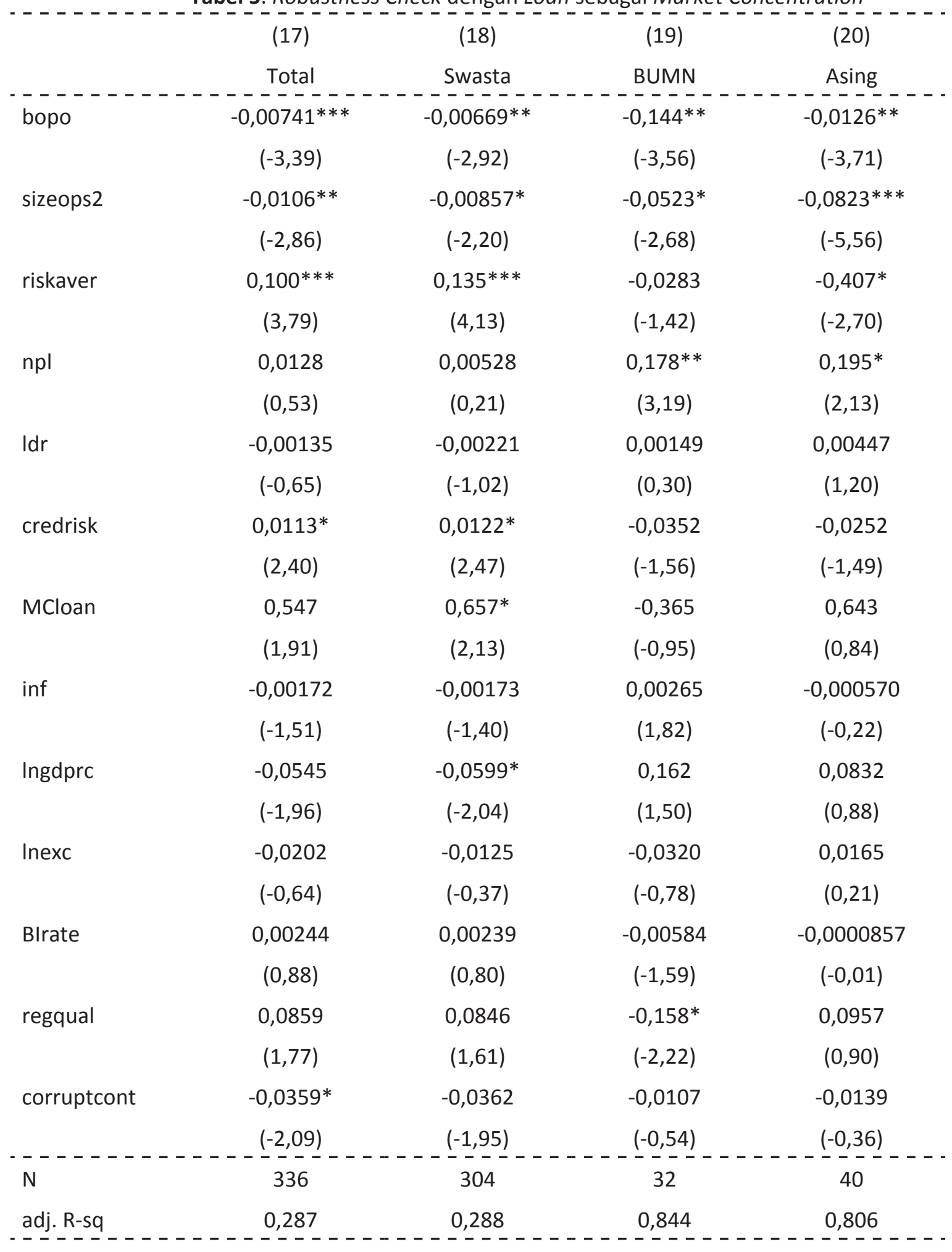

Keterangan: nilai t-stat berada dalam kurung.

$*: p<0,05, * *: p<0,01$, dan $* * *: p<0,001$ 